\title{
Evaluation of the MACC operational forecast system - potential and challenges of global near-real-time modelling with respect to reactive gases in the troposphere
}

\author{
A. Wagner ${ }^{1}$, A.-M. Blechschmidt ${ }^{2}$, I. Bouarar ${ }^{3, a}$, E.-G. Brunke ${ }^{4}$, C. Clerbaux $^{3}$, M. Cupeiro ${ }^{5}$, P. Cristofanelli ${ }^{6}$, \\ H. Eskes ${ }^{7}$, J. Flemming ${ }^{8}$, H. Flentje ${ }^{1}$, M. George ${ }^{3}$, S. Gilge ${ }^{1}$, A. Hilboll ${ }^{2}$, A. Inness ${ }^{8}$, J. Kapsomenakis ${ }^{9}$, A. Richter ${ }^{2}$, \\ L. Ries ${ }^{10}$, W. Spangl ${ }^{11}$, O. Stein ${ }^{12}$, R. Weller ${ }^{13}$, and C. Zerefos ${ }^{9}$ \\ ${ }^{1}$ Deutscher Wetterdienst, Meteorologisches Observatorium Hohenpeissenberg, Hohenpeissenberg, Germany \\ ${ }^{2}$ Institute of Environmental Physics, University of Bremen, Bremen, Germany \\ ${ }^{3}$ Sorbonne Universités, UPMC Univ. Paris 06, Université Versailles St-Quentin, CNRS/INSU, LATMOS-IPSL, \\ Paris, France \\ ${ }^{4}$ South African Weather Service, Stellenbosch, South Africa \\ ${ }^{5}$ National Meteorological Service, Ushuaia, Tierra del Fuego, Argentina \\ ${ }^{6}$ National Research Council of Italy, ISAC, Bologna, Italy \\ ${ }^{7}$ Royal Netherlands Meteorological Institute, De Bilt, the Netherlands \\ ${ }^{8}$ European Centre for Medium-range Weather Forecasts, Reading, UK \\ ${ }^{9}$ Academy of Athens, Research Centre for Atmospheric Physics and Climatology, Athens, Greece \\ ${ }^{10}$ Federal Environment Agency, GAW Global Station Zugspitze/Hohenpeissenberg, Zugspitze 5, \\ 82475 Zugspitze, Germany \\ ${ }^{11}$ Umweltbundesamt GmbH, Air Pollution Control \& Climate Change Mitigation, Vienna, Austria \\ ${ }^{12}$ Forschungszentrum Jülich, IEK-8 (Troposphere), Jülich, Germany \\ ${ }^{13}$ Alfred Wegener Institute, Bremerhaven, Germany \\ ${ }^{a}$ now at: Max Planck Institute for Meteorology, Hamburg, Germany
}

Correspondence to: A. Wagner (annette.wagner@dwd.de)

Received: 7 October 2014 - Published in Atmos. Chem. Phys. Discuss.: 4 March 2015

Revised: 30 October 2015 - Accepted: 7 November 2015 - Published: 18 December 2015

\begin{abstract}
The Monitoring Atmospheric Composition and Climate (MACC) project represents the European Union's Copernicus Atmosphere Monitoring Service (CAMS) (http: //www.copernicus.eu/), which became fully operational during 2015. The global near-real-time MACC model production run for aerosol and reactive gases provides daily analyses and 5-day forecasts of atmospheric composition fields. It is the only assimilation system worldwide that is operational to produce global analyses and forecasts of reactive gases and aerosol fields. We have investigated the ability of the MACC analysis system to simulate tropospheric concentrations of reactive gases covering the period between 2009 and 2012. A validation was performed based on carbon monoxide $(\mathrm{CO})$, nitrogen dioxide $\left(\mathrm{NO}_{2}\right)$ and ozone $\left(\mathrm{O}_{3}\right)$ surface obser-
\end{abstract}

vations from the Global Atmosphere Watch (GAW) network, the $\mathrm{O}_{3}$ surface observations from the European Monitoring and Evaluation Programme (EMEP) and, furthermore, $\mathrm{NO}_{2}$ tropospheric columns, as well as $\mathrm{CO}$ total columns, derived from satellite sensors. The MACC system proved capable of reproducing reactive gas concentrations with consistent quality; however, with a seasonally dependent bias compared to surface and satellite observations - for northern hemispheric surface $\mathrm{O}_{3}$ mixing ratios, positive biases appear during the warm seasons and negative biases during the cold parts of the year, with monthly modified normalised mean biases (MNMBs) ranging between -30 and $30 \%$ at the surface. Model biases are likely to result from difficulties in the simulation of vertical mixing at night and deficiencies in the model's dry 
deposition parameterisation. Observed tropospheric columns of $\mathrm{NO}_{2}$ and $\mathrm{CO}$ could be reproduced correctly during the warm seasons, but are mostly underestimated by the model during the cold seasons, when anthropogenic emissions are at their highest level, especially over the US, Europe and Asia. Monthly MNMBs of the satellite data evaluation range from values between -110 and $40 \%$ for $\mathrm{NO}_{2}$ and at most $-20 \%$ for $\mathrm{CO}$, over the investigated regions. The underestimation is likely to result from a combination of errors concerning the dry deposition parameterisation and certain limitations in the current emission inventories, together with an insufficiently established seasonality in the emissions.

\section{Introduction}

The impact of reactive gases on climate, human health and the environment has gained increasing public and scientific interest in the last decade (Bell et al., 2006; Cape 2008; Mohnen et al., 1993; Seinfeld and Pandis 2006; Selin et al., 2009) as air pollutants such as carbon monoxide (CO), nitrogen oxides $\left(\mathrm{NO}_{x}\right)$ and ozone $\left(\mathrm{O}_{3}\right)$ are known to have acute and chronic effects on human health, ranging from minor upper respiratory irritation to chronic respiratory and heart disease, lung cancer, acute respiratory infections in children and chronic bronchitis in adults (Bell et al., 2006; Kampa and Castanas, 2006). Tropospheric ozone, even in small concentrations, is also known to cause plant damage through reducing plant primary productivity as well as crop yields (e.g. Ashmore, 2005). It also contributes to global warming by direct and indirect radiative forcing (Forster et al., 2007; Sitch et al., 2007). Pollution events can be caused by local sources and processes but are also influenced by continental and intercontinental transport of air masses. Global models can provide the transport patterns of air masses and deliver the boundary conditions for regional models, facilitating the forecast and investigation of air pollutants.

The European Union (EU)-funded research project Monitoring Atmospheric Composition and Climate (MACC) (consisting of a series of European projects, MACC to MACC-III), provides the preparatory work that will form the basis of the European Union's Copernicus Atmosphere Monitoring Service (CAMS). This service was established by the EU to provide a range of products of societal and environmental value with the aim to help European governments respond to climate change and air quality problems (more information about this service can be found on CAMS website http://www.copernicus.eu/main/ atmosphere-monitoring). The MACC project provides reanalyses, monitoring products of atmospheric key constituents (e.g. Inness et al., 2013), as well as operational daily forecasting of greenhouse gases, aerosols and reactive gases (Benedetti et al., 2011; Stein et al., 2012) on a global and on European-scale level, and derived products such as solar radiation. An important aim of the MACC system is to describe the occurrence, magnitude and transport pathways of disruptive events, e.g., volcanoes (Flemming and Inness, 2013), major fires (Huijnen et al., 2012; Kaiser et al., 2012) and dust storms (Cuevas et al., 2015). The product catalogue can be found on the MACC website: http://copernicus-atmosphere.eu. For the generation of atmospheric products, state-of-the-art atmospheric modelling is combined with assimilated satellite data (Hollingsworth et al., 2008; Inness et al., 2013, 2015; more general information about data assimilation can be found in, e.g., BallabreraPoy et al., 2009 or Kalnay, 2003). Within the MACC project there is a dedicated validation activity to provide up-to-date information on the quality of the reanalysis, daily analyses and forecasts. Validation reports are updated regularly and are available on the MACC websites.

The MACC global near-real-time (NRT) production model for reactive gases and aerosol has operated with data assimilation from September 2009 onwards, providing boundary conditions for the MACC regional air quality (RAQ) products, and other downstream users. The model simulations also provide input for the stratospheric ozone analyses delivered in near-real-time by the MACC stratospheric ozone system (Lefever et al., 2014).

In this paper we describe the investigation of the potential and challenges of near-real-time modelling with the MACC analysis system between 2009 and 2012. We concentrate on this period because of the availability of validated independent observations, namely surface observations from the Global Atmosphere Watch (GAW) Programme, the European Monitoring and Evaluation Programme (EMEP), as well as total column/tropospheric column satellite data from the MOPITT (Measurement Of Pollution In The Troposphere), SCIAMACHY (SCanning Imaging Absorption spectroMeter for Atmospheric CHartographY) and GOME2 (Global Ozone Monitoring Experiment-2) sensors. In particular, we study the model's ability to reproduce the seasonality and absolute values of $\mathrm{CO}$ and $\mathrm{NO}_{2}$ in the troposphere as well as $\mathrm{NO}_{2}, \mathrm{O}_{3}$ and $\mathrm{CO}$ at the surface. The impact of changes in model version, data assimilation and emission inventories on the model performance is examined and discussed. The paper is structured in the following way: Sect. 2 contains a description of the model and the validation data sets as well as the applied validation metrics. Section 3 presents the validation results for $\mathrm{CO}, \mathrm{NO}_{2}$ and $\mathrm{O}_{3}$. Section 4 provides the discussion and Sect. 5 the conclusions of the paper.

\section{Data and methods}

\subsection{The MACC model system in the 2009-2012 period}

The MACC global products for reactive gases consist of a reanalysis performed for the years 2003-2012 (Inness et al., 2013) and the near-real-time analysis and forecast, largely 
based on the same assimilation and forecasting system, but targeting different user groups (operational air quality forecasting and regional climate modelling, respectively). The Model for OZone And Related chemical Tracers (MOZART) chemical transport model (CTM) is coupled to the integrated forecast system (IFS) of the European Centre for MediumRange Weather Forecast (ECMWF), which together represent the MOZART-IFS model system (Flemming et al., 2009; Stein et al., 2012). An alternative analysis system has been set up based on the global chemistry transport model version 5 (TM5; see also Huijnen et al., 2010). Details of the MOZART version used in the MACC global products can be found in Kinnison et al. (2007) and Stein et al. (2011, 2012). In our simulation, the IFS and the MOZART model run in parallel and exchange several two- and three-dimensional fields every model hour using the Ocean Atmosphere Sea Ice Soil version 4 (OASIS4) coupling software (Valcke and Redler, 2006), thereby producing three-dimensional IFS fields for $\mathrm{O}_{3}, \mathrm{CO}, \mathrm{SO}_{2}, \mathrm{NO}_{x}, \mathrm{HCHO}$, sea salt aerosol, desert dust, black carbon, organic matter, and total aerosol. The IFS provides meteorological data to MOZART. Data assimilation and transport of the MACC species takes place in the IFS, while the whole chemical reaction system is calculated in the MOZART model.

The MACC_osuite (operational suite) is the global nearreal-time MACC model production run for aerosol and reactive gases. Here, we have investigated only the MACC analysis. In contrast to the reanalysis, the MACC_osuite is a near-real-time run, which implies that it is only run once in near-real-time and may thus contain inconsistencies in, e.g., the assimilated data. The MACC_osuite was based on the IFS cycle CY36R1 with IFS model resolution of approximately $100 \mathrm{~km}$ by $100 \mathrm{~km}$ at 60 levels (T159L60) from September 2009 to July 2012. The gas-phase chemistry module in this cycle is based on MOZART version 3.0 (Kinnison et al., 2007). The model has been upgraded, following updates of the ECMWF meteorological model and MACCspecific updates, i.e. in chemical data assimilation and with respect to the chemical model itself. Thus, from July 2012 onwards, the MACC_osuite has run with a change of the meteorological model to a new IFS cycle (version CY37R3), with an IFS model resolution of approximately $80 \mathrm{~km}$ at 60 levels (T255L60) and an upgrade of the MOZART version 3.5 (Kinnison et al., 2007; Emmons et al., 2011; Stein et al., 2013). This includes, amongst others, updated velocity fields for the dry deposition of $\mathrm{O}_{3}$ over ice, as described in Stein et al. (2013). A detailed documentation of system changes can be found at http://atmosphere.copernicus. eu/user-support/operational-info.

\section{Emission inventories and assimilated data sets}

In the MACC_osuite, anthropogenic emissions are based on emissions from the EU project REanalysis of the TRopospheric chemical composition Over (RETRO) the past
40 years merged with updated emissions for East Asia from the Regional Emission inventory in ASia (REAS) inventory (Schultz et al., 2007) - in the following referred to as RETRO-REAS. The horizontal resolution is $0.5^{\circ}$ in latitude and longitude and it contains a monthly temporal resolution. Biogenic emissions are taken from Global Emissions InitiAtive (GEIA), fire emissions are based on a climatology derived from Global Fire Emissions Database version 2 (GFEDv2; van der Werf et al., 2006) until April 2010, when fire emissions change to global fire assimilation system (GFAS) emissions (Kaiser et al., 2012). Between January and October 2011 there has been a fire emission reading error in the model where, instead of adjusting emissions to the appropriate month, the same set of emissions have been read throughout this period.

After the model upgrade to the new cycle version CY37R3, in July 2012, the emission inventories changed from the merged RETRO-REAS and GEIA inventories, used in the previous cycle, to the MACCity (MACC/CityZEN EU projects) anthropogenic and biogenic emissions (Granier et al., 2011) and (climatological) Model of Emissions of Gases and Aerosols from Nature version 2 (MEGAN-v2; see Guenther et al., 2006) emission inventories. Wintertime anthropogenic $\mathrm{CO}$ emissions are scaled up over Europe and North America (see Stein et al., 2014). Near-real-time fire emissions are taken from GFASv1.0 (Kaiser et al., 2012), for both gas-phase and aerosol.

In the MACC_osuite, the initial conditions for some of the chemical species are provided by data assimilation of atmospheric composition observations from satellites (see Benedetti et al., 2008; Inness et al., 2009, 2013; Massart et al., 2014). Table 1 lists the assimilated data products. From September 2009 to June 2012, $\mathrm{O}_{3}$ total columns from the microwave limb sounder (MLS) and solar backscatter ultraviolet (SBUV-2) instruments are assimilated, as well as ozone monitoring instrument (OMI) and SCIAMACHY total columns (the latter only until March 2012, when the European Space Agency lost contact with the ENVIronmental SATellite - ENVISAT). The CO total columns are assimilated from the Infrared Atmospheric Sounding Interferometer (IASI) sensor and aerosol total optical depth is assimilated from the Moderate Resolution Imaging Spectroradiometer (MODIS) instrument. After the model cycle update in July 2012, data assimilation also includes OMI tropospheric columns of $\mathrm{NO}_{2}$ and $\mathrm{SO}_{2}$, as well as CO MOPITT total columns.

Tables 1 and 2 summarise the data assimilation and set-up of the MACC_osuite.

\subsection{Validation data and methodology}

In this study, we have tended to use the same evaluation data sets as during the MACC near-real-time validation exercise. This implies some discontinuities in the evaluations, e.g. the substitution of SCIAMACHY data with GOME-2 data after 
Table 1. List of assimilated data in the MACC_osuite.

\begin{tabular}{llllll}
\hline Instrument & Satellite & Provider & Version & Type & Status (YYYYMMDD) \\
\hline MLS & AURA & NASA & V02 & $\mathrm{O}_{3}$ Profiles & $20090901-20121231$ \\
OMI & AURA & NASA & V883 & $\mathrm{O}_{3}$ Total column & $20090901-20121231$ \\
SBUV-2 & NOAA & NOAA & $\mathrm{V} 8$ & $\mathrm{O}_{3}$ 6 layer profiles & $20090901-20121231$ \\
SCIAMACHY & Envisat & KNMI & & $\mathrm{O}_{3}$ total column & $20090916-20120408$ \\
IASI & MetOp-A & LATMOS/ULB & V20100815 & CO Total column & $20090901-20121231$ \\
MOPITT & TERRA & NCAR & V4 & CO Total column & $20120705-20121231$ \\
OMI & AURA & KNMI & DOMINO V2.0 & NO $_{2}$ Tropospheric column & $20120705-20121231$ \\
OMI & AURA & NASA & v003 & SO T Tropospheric column & $20120705-20121231$ \\
MODIS & AQUA/TERRA & NASA & Col. 5 & Aerosol total optical depth & $20090901-20121231$ \\
\hline
\end{tabular}

Table 2. Description of the set-up of the MACC_osuite between September 2009 and December 2012. Details on the assimilated data are provided in Table 1. A description of the emissions is given in Sect. "Emission inventories and assimilated data sets" in the text.

\begin{tabular}{|c|c|c|c|}
\hline Model cycle & CTM & Assimilated data & Emissions \\
\hline CY36R1 & MOZART v3.0 & $\begin{array}{l}\mathrm{O}_{3} \text { (MLS, OMI, SBUV-2 SCIAMACHY), } \\
\mathrm{CO} \text { (IASI) }\end{array}$ & RETRO/REAS/GEIA/GFEDv2/GFAS \\
\hline CY37R3 & MOZART v3.5 & $\begin{array}{l}\mathrm{O}_{3} \text { (MLS, OMI, SBUV-2), CO (IASI, MO- } \\
\text { PITT), } \mathrm{NO}_{2}(\mathrm{OMI}), \mathrm{SO}_{2}(\mathrm{OMI})\end{array}$ & MACCity / MEGAN / GFASv1.0 daily \\
\hline
\end{tabular}

the loss of the Envisat sensor or an exclusion of MOPITT satellite data after the start of its assimilation into the model. The continuous process of updating and complementation of data sets in databases requires the selection and definition of a validation data set at some point. The comparatively small inconsistencies between our data sets are considered to have a negligible impact on the overall evaluation results.

\subsubsection{GAW surface $\mathrm{O}_{3}, \mathrm{CO}$ and $\mathrm{NO}_{2}$ observations}

The GAW programme of the World Meteorological Organisation (WMO) has been established to provide reliable longterm observations of the chemical composition and physical properties of the atmosphere, which are relevant for understanding atmospheric chemistry and climate change (WMO, 2013). The GAW tropospheric $\mathrm{O}_{3}$ measurements are performed in a way to be suited for the detection of long-term regional and global changes. Furthermore, the GAW measurement programme focusses on observations that are regionally representative and should be free from influence of significant local pollution sources and suited for the validation of global chemistry climate models (WMO, 2007). Detailed information on GAW- and GAW-related $\mathrm{O}_{3}, \mathrm{CO}$ and $\mathrm{NO}_{2}$ measurements can be found in WMO $(2010,2011,2013)$ and Penkett (2011).

Hourly $\mathrm{O}_{3}, \mathrm{CO}$ and $\mathrm{NO}_{2}$ data have been downloaded from the WMO/GAW World Data Centre for Greenhouse Gases (WDCGG) for the period between September 2009 and December 2012 (the download was carried out in July 2013). Our validation includes 6 stations with surface observations for $\mathrm{NO}_{2}, 29$ stations for $\mathrm{CO}$ and 50 stations with surface ob- servations for $\mathrm{O}_{3}$. Table 3 lists the geographic coordinates and altitudes of the individual stations. Being a long-term data network, the data in the database are provided with a temporal delay of approximately 2 years. As the data in the database become sparse towards the end of the validation period, near-real-time observations, as used in the MACCproject for near-real-time validation, presented on the MACC website, have been included to complement the validation data sets. For the detection of long-term trends and year-toyear variability, the data quality objectives (DQOs) for $\mathrm{CO}$ in GAW measurements are set to a maximum uncertainty of $\pm 2 \mathrm{ppb}$ and to $\pm 5 \mathrm{ppb}$ for marine boundary layer sites and continental sites that are influenced by regional pollution, and to $\pm 1 \mathrm{ppb}$ for ozone (WMO, 2012, 2013) and $0.08 \mathrm{ppb}$ for $\mathrm{NO}_{2}$ (WMO, 2011).

For the validation with GAW station data, 6-hourly values (00:00, 06:00, 12:00, 18:00 UTC) of the analysis mode have been extracted from the model and are matched with hourly observational GAW station data. Model mixing ratios at the stations' locations have been linearly interpolated from the model data in the horizontal. In the vertical, modelled gas mixing ratios have been extracted at the model level, which is closest to the GAW stations' altitude. Validation scores (see Sect. 2.3) have been calculated for each station between the 6-hourly model analysis data and the corresponding observational data for the entire period (September 2009-December 2012) and as monthly averages. 
Table 3. List of GAW and EMEP stations used in the evaluation (GAW listed by label, EMEP listed by region: northern Europe NE; central Europe CE; and southern Europe, SE). The numbers by the station name provide the type of gas: $a=\mathrm{O}_{3}, \mathrm{~b}=\mathrm{CO}, \mathrm{c}=\mathrm{NO}_{2}$. Positive latitude values refer to the Northern Hemisphere, negative latitude values to the Southern Hemisphere.

\begin{tabular}{|c|c|c|c|c|c|c|c|c|c|c|c|}
\hline Station & Label/region & Programme & Lat $\left[{ }^{\circ}\right]$ & Long $\left[{ }^{\circ}\right]$ & Alt [m a.s.1.] & Station & Label/region & Programme & Lat $\left[{ }^{\circ}\right]$ & Long $\left[{ }^{\circ}\right]$ & Alt [m a.s.1.] \\
\hline Ähtäri II ${ }^{\mathrm{a}}$ & NE & EMEP & 62.58 & 24.18 & 180 & Masenberg $^{\mathrm{a}}$ & CE & EMEP & 47.35 & 15.88 & 1170 \\
\hline Alert $^{\mathrm{b}}$ & ALT & GAW & 82.45 & -62.52 & 210 & Mauna Loa ${ }^{a}$ & MAU & GAW & 19.54 & -155.58 & 3397 \\
\hline Arrival Heights ${ }^{\mathrm{a}}$ & ARH & GAW & -77.80 & 166.67 & 184 & Minamitorishima $^{\mathrm{a}, \mathrm{b}}$ & MNM & GAW & 24.29 & 153.98 & 8 \\
\hline Aspvreten $^{\mathrm{a}}$ & NE & EMEP & 58.80 & 17.38 & 20 & Montandon $^{\mathrm{a}}$ & $\mathbf{C E}$ & EMEP & 47.30 & 6.83 & 836 \\
\hline Assekrem $^{\mathrm{a}}$ & ASS & GAW & 23.27 & 5.63 & 2710 & Monte Cimone $^{\mathrm{a}, \mathrm{b}}$ & MCI & GAW & 44.18 & 10.70 & 2165 \\
\hline Aston Hill ${ }^{\mathrm{a}}$ & NE & EMEP & 52.50 & -3.03 & 370 & Monte Velho ${ }^{\mathrm{a}}$ & SE & EMEP & 38.08 & -8.80 & 43 \\
\hline Auchencorth $^{\mathrm{a}}$ & NE & EMEP & 55.79 & -3.24 & 260 & Montelibretti $^{\mathrm{a}}$ & $\mathbf{C E}$ & EMEP & 42.10 & 12.63 & 48 \\
\hline Ayia Marina $^{\mathrm{a}}$ & SE & EMEP & 35.04 & 33.06 & 532 & Montfranc ${ }^{\mathrm{a}}$ & $\mathbf{C E}$ & EMEP & 45.80 & 2.07 & 810 \\
\hline Barcarrola $^{\mathrm{a}}$ & SE & EMEP & 38.47 & -6.92 & 393 & Morvan $^{\mathrm{a}}$ & CE & EMEP & 47.27 & 4.08 & 620 \\
\hline Baring Head ${ }^{\mathrm{a}}$ & BAH & GAW & -41.41 & 174.87 & 85 & Narberth $^{\mathrm{a}}$ & NE & EMEP & 51.23 & -4.70 & 160 \\
\hline Barrow $^{\mathrm{a}}$ & BAR & GAW & 71.32 & -156.60 & 11 & Neuglobsow ${ }^{\mathrm{a}, \mathrm{b}}$ & NGW/NE & GAW/EMEP & 53.17 & 13.03 & 62 \\
\hline BEO Moussala ${ }^{a, b}$ & BEO & GAW & 42.18 & 23.59 & 2925 & Neumayer $^{\mathrm{a}}$ & NEU & GAW & -70.65 & -8.25 & 42 \\
\hline Birkenes $^{\mathrm{a}}$ & NE & EMEP & 58.38 & 8.25 & 190 & Niembro $^{a}$ & $\mathbf{C E}$ & EMEP & 43.44 & -4.85 & 134 \\
\hline Bredkälen $^{\mathrm{a}}$ & NE & EMEP & 63.85 & 15.33 & 404 & Norra-Kvill $^{\mathrm{a}}$ & NE & EMEP & 57.81 & 15.56 & 261 \\
\hline Bush $^{\mathrm{a}}$ & NE & EMEP & 55.86 & -3.21 & 180 & O Saviñao ${ }^{\mathrm{a}}$ & $\mathbf{C E}$ & EMEP & 43.23 & -7.70 & 506 \\
\hline Cabauw $^{\mathrm{a}}$ & NE & EMEP & 51.97 & 4.92 & 60 & Offagne $^{\mathrm{a}}$ & $\mathbf{C E}$ & EMEP & 49.88 & 5.20 & 430 \\
\hline Cabo de Creus $^{\mathrm{a}}$ & $\mathbf{C E}$ & EMEP & 42.32 & 3.32 & 23 & Oulanka $^{\mathrm{a}}$ & NE & EMEP & 66.32 & 29.40 & 310 \\
\hline Cairo $^{\mathrm{a}}$ & CAI & GAW & 30.08 & 31.28 & 35 & Pallas $^{\mathrm{a}}$ & NE & EMEP & 68.00 & 24.15 & 340 \\
\hline Campisabalos $^{\mathrm{a}}$ & $\mathbf{C E}$ & EMEP & 41.28 & -3.14 & 1360 & Payerne $e^{a, b}$ & $\mathrm{PAY} / \mathrm{CE}$ & GAW/EMEP & 46.81 & 6.94 & 510 \\
\hline Cape Grim ${ }^{\mathrm{a}}$ & CAG & GAW & -40.68 & 144.68 & 94 & Penausende $^{\mathrm{a}}$ & CE & EMEP & 41.28 & -5.86 & 985 \\
\hline Cape Point ${ }^{\mathrm{a}, \mathrm{b}}$ & CAP & GAW & -34.35 & 18.48 & 230 & Peyrusse Vieille $^{\mathrm{a}}$ & $\mathbf{C E}$ & EMEP & 43.62 & 0.18 & 200 \\
\hline Cape Verde ${ }^{\mathrm{a}, \mathrm{b}}$ & $\mathrm{CVO}$ & GAW & 16.85 & -24.87 & 10 & Pic du Midi ${ }^{\mathrm{a}, \mathrm{b}}$ & $\mathrm{PIC} / \mathbf{C E}$ & GAW/EMEP & 42.94 & 0.14 & 2877 \\
\hline Charlton Mackrell ${ }^{\mathrm{a}}$ & NE & EMEP & 51.06 & -2.68 & 54 & Pillersdor $^{\mathrm{a}}$ & $\mathbf{C E}$ & EMEP & 48.72 & 15.94 & 315 \\
\hline Chaumont $^{\mathrm{a}}$ & $\mathbf{C E}$ & EMEP & 47.05 & 6.98 & 1130 & Preila $^{\mathrm{a}}$ & NE & EMEP & 55.35 & 21.07 & 5 \\
\hline Chibougamau ${ }^{\mathrm{b}}$ & $\mathrm{CHI}$ & GAW & 49.68 & -74.34 & 393 & Prestebakke ${ }^{a}$ & NE & EMEP & 59.00 & 11.53 & 160 \\
\hline Chopok $^{\mathrm{a}}$ & $\mathbf{C E}$ & EMEP & 48.93 & 19.58 & 2008 & Puy de Dôme ${ }^{a, b}$ & PUY/CE & GAW/EMEP & 45.77 & 2.95 & 1465 \\
\hline Concordia $^{\mathrm{a}}$ & $\mathrm{CON}$ & GAW & -75.10 & 123.33 & 3233 & Ragged Point ${ }^{\mathrm{a}}$ & RAG & GAW & 13.17 & -59.43 & 45 \\
\hline De Zilk ${ }^{\mathrm{a}}$ & NE & EMEP & 52.30 & 4.50 & 4 & $\mathrm{Rao}^{\mathrm{a}}$ & NE & EMEP & 57.39 & 11.91 & 10 \\
\hline Diabla Gora $^{a}$ & NE & EMEP & 54.15 & 22.07 & 157 & Revin $^{\mathrm{a}}$ & CE & EMEP & 49.90 & 4.63 & 390 \\
\hline Dobele $^{\mathrm{a}}$ & DOB & GAW & 56.37 & 23.19 & 42 & $\operatorname{Rigi}^{\mathrm{a}, \mathrm{b}, \mathrm{c}}$ & $\mathrm{RIG} / \mathrm{CE}$ & GAW/EMEP & 47.07 & 8.46 & 1030 \\
\hline Doñana $^{a}$ & SE & EMEP & 37.03 & -6.33 & 5 & Rojen Peak $^{\mathrm{a}}$ & CE & EMEP & 41.70 & 24.74 & 1750 \\
\hline Donon $^{\mathrm{a}}$ & $\mathbf{C E}$ & EMEP & 48.50 & 7.13 & 775 & Rucava $^{\mathrm{a}}$ & RUC/NE & GAW/EMEP & 56.10 & 21.10 & 18 \\
\hline Dunkelsteinerwald $^{\mathrm{a}}$ & $\mathbf{C E}$ & EMEP & 48.37 & 15.55 & 320 & Ryori ${ }^{\mathrm{a}, \mathrm{b}}$ & RYO & GAW & 39.03 & 141.82 & 260 \\
\hline East Trout Lake ${ }^{\mathrm{b}}$ & ETL & GAW & 54.35 & -104.98 & 492 & Sable Island ${ }^{\mathrm{b}}$ & SAB & GAW & 43.93 & -60.02 & 5 \\
\hline Egbert $^{b}$ & EGB & GAW & 44.23 & -79.78 & 253 & San Pablo de los Montes ${ }^{a}$ & SE & EMEP & 39.55 & -4.35 & 917 \\
\hline Eibergen $^{a}$ & NE & EMEP & 52.08 & 6.57 & 20 & Sandve $\mathrm{a}^{\mathrm{a}}$ & NE & EMEP & 59.20 & 5.20 & 15 \\
\hline Els Torms ${ }^{\mathrm{a}}$ & $\mathbf{C E}$ & EMEP & 41.40 & 0.72 & 470 & Schauinsland $\mathrm{a}^{\mathrm{a}, \mathrm{b}, \mathrm{c}}$ & $\mathrm{SCH} / \mathbf{C E}$ & GAW/EMEP & 47.92 & 7.92 & 1205 \\
\hline Eskdalemuir $^{\mathrm{a}}$ & NE & EMEP & 55.31 & -3.20 & 243 & Schmücke ${ }^{\mathrm{a}}$ & NE & EMEP & 50.65 & 10.77 & 937 \\
\hline Esrange $^{\mathrm{a}}$ & NE & EMEP & 67.88 & 21.07 & 475 & Sibton $^{\mathrm{a}}$ & NE & EMEP & 52.29 & 1.46 & 46 \\
\hline Estevan Point ${ }^{\mathrm{a}, \mathrm{b}}$ & ESP & GAW & 49.38 & -126.55 & 39 & Śnieżka ${ }^{a}$ & NE & EMEP & 50.73 & 15.73 & 1603 \\
\hline Eupen $^{\mathrm{a}}$ & $\mathrm{NE}$ & EMEP & 51.46 & 6.00 & 295 & Sonnblick $^{\mathrm{a}, \mathrm{b}, \mathrm{c}}$ & SBL/CE & GAW/EMEP & 47.05 & 12.96 & 3106 \\
\hline
\end{tabular}

\subsubsection{EMEP surface $\mathrm{O}_{3}$ observations}

The EMEP is a scientifically based and policy driven programme under the Convention on Long-Range Transboundary Air Pollution (CLRTAP) for international co-operation to solve transboundary air pollution problems. Measurements of air quality in Europe have been carried out under the EMEP programme since 1977.

A detailed description of the EMEP measurement programme can be found in Tørseth et al. (2012). The surface hourly ozone data between September 2009 and December 2012 have been downloaded from the EMEP data web page (http://www.nilu.no/projects/ccc/emepdata.html). For the validation, only stations meeting the $75 \%$ availability threshold per day and per month are taken into account. The precision is close to $1.5 \mathrm{ppb}$ for a $10 \mathrm{~s}$ measurement. More information about the ozone data quality, calibration and maintenance procedures can be found in Aas et al. (2000).

For comparison with EMEP data, 3-hourly model values (00:00, 03:00, 06:00, 12:00, 15:00, 18:00, 21:00 UTC) of the analysis mode have been chosen. We used this data set to test the dependency of the biases on a daytime and nighttime basis, separately. Gas mixing ratios have been extracted from the model and are matched with hourly observational surface ozone data at 124 EMEP stations in the same way as for the GAW station data. The EMEP surface ozone values and the interpolated surface modelled values are compared on a monthly basis for the latitude bands of $30-40^{\circ} \mathrm{N}$ (southern Europe), 40-50 ${ }^{\circ} \mathrm{N}$ (central Europe) and $50-70^{\circ} \mathrm{N}$ (northern Europe). For the identification of differences in the MACC_osuite performance between day and night-time, the MACC_osuite simulations and the EMEP observations for the three latitude bands have been additionally separated into daytime (12:00-15:00 local time, LT) and night-time (00:00 03:00 LT) intervals.

\subsubsection{MOPITT CO total column retrievals}

The MOPITT instrument is mounted on board the NASA EOS Terra satellite and provides CO distributions at the global scale (Deeter et al., 2004). The MOPITT instrument has a horizontal resolution of $22 \mathrm{~km} \times 22 \mathrm{~km}$ and allows for 
Table 3. Continued.

\begin{tabular}{|c|c|c|c|c|c|c|c|c|c|c|c|}
\hline Station & Label/region & Programme & Lat $\left[{ }^{\circ}\right]$ & Long $\left[{ }^{\circ}\right]$ & Alt [m a.s.1.] & Station & Label/region & Programme & Lat $\left[{ }^{\circ}\right]$ & Long $\left[{ }^{\circ}\right]$ & Alt [m a.s.l.] \\
\hline Everest - Pyramid ${ }^{\mathrm{a}}$ & EVP & GAW & 27.96 & 86.82 & 5079 & South Pole ${ }^{\mathrm{a}}$ & SPO & GAW & -89.98 & -24.80 & 2810 \\
\hline Finokalia $^{\mathrm{a}}$ & SE & EMEP & 35.32 & 25.67 & 250 & Spitsbergen $^{\mathrm{a}}$ & NE & EMEP & 78.90 & 11.88 & 474 \\
\hline Forsthof $^{\mathrm{a}}$ & $\mathbf{C E}$ & EMEP & 48.10 & 15.91 & 581 & St. Osyth ${ }^{\mathrm{a}}$ & NE & EMEP & 51.78 & 1.08 & 8 \\
\hline Fraserdale $^{b}$ & FRA & GAW & 49.88 & -81.57 & 210 & Stará Lesnáa & CE & EMEP & 49.15 & 20.28 & 808 \\
\hline Gänserndorf $^{\mathrm{a}}$ & CE & EMEP & 48.33 & 16.73 & 161 & Starina $^{\mathrm{a}}$ & CE & EMEP & 49.05 & 22.27 & 345 \\
\hline Gerlitzen $^{\mathrm{a}}$ & CE & EMEP & 46.69 & 13.92 & 1895 & Stixneusiedl ${ }^{\mathrm{a}}$ & CE & EMEP & 48.05 & 16.68 & 240 \\
\hline Graz Platte $^{\mathrm{a}}$ & CE & EMEP & 47.11 & 15.47 & 651 & Strath Vaich Dam ${ }^{\mathrm{a}}$ & NE & EMEP & 57.73 & -4.77 & 270 \\
\hline Great Dun Fell ${ }^{\mathrm{a}}$ & NE & EMEP & 54.68 & -2.45 & 847 & Summit $^{\mathrm{a}}$ & SUM & GAW & 72.58 & -38.48 & 3238 \\
\hline Grimsoe $^{\mathrm{a}}$ & NE & EMEP & 59.73 & 15.47 & 132 & Syowa Station ${ }^{\mathrm{a}}$ & SYO & GAW & -69.00 & 39.58 & 16 \\
\hline Harwell $^{\mathrm{a}}$ & NE & EMEP & 51.57 & -1.32 & 137 & Tänikon $^{\mathrm{a}}$ & $\mathrm{CE}$ & EMEP & 47.48 & 8.90 & 540 \\
\hline Haunsberg $^{\mathrm{a}}$ & CE & EMEP & 47.97 & 13.02 & 730 & Topolniky $^{\mathrm{a}}$ & CE & EMEP & 47.96 & 17.86 & 113 \\
\hline Heidenreichstein $^{\mathrm{a}}$ & CE & EMEP & 48.88 & 15.05 & 570 & Trinidad Head $^{\mathrm{a}}$ & TRI & GAW & 41.05 & -124.15 & 120 \\
\hline High Muffles $^{\mathrm{a}}$ & NE & EMEP & 54.33 & -0.80 & 267 & Tsukuba $^{\mathrm{a}}$ & TSU & GAW & 36.05 & 140.13 & 25 \\
\hline Hurdal $^{\mathrm{a}}$ & NE & EMEP & 60.37 & 11.08 & 300 & Tudor Hill $^{\mathrm{a}}$ & TUD & GAW & 32.27 & -64.87 & 30 \\
\hline Illmitz $^{\mathrm{a}}$ & CE & EMEP & 47.77 & 16.77 & 117 & Tustervatn $^{\mathrm{a}}$ & NE & EMEP & 65.83 & 13.92 & 439 \\
\hline Iskrba $^{\mathrm{a}}$ & ISK/CE & GAW/EMEP & 45.56 & 14.86 & 520 & Tutuila $^{\mathrm{a}}$ & TUT & GAW & -14.24 & -170.57 & 42 \\
\hline Izaña (Tenerife) $)^{a, b}$ & IZO & GAW & 28.30 & -16.50 & 2367 & Ushuaia $^{\mathrm{a}, \mathrm{b}}$ & USH & GAW & -54.85 & -68.32 & 18 \\
\hline Karasjok $^{\mathrm{a}}$ & NE & EMEP & 69.47 & 25.22 & 333 & Vezin $^{\mathrm{a}}$ & NE & EMEP & 50.50 & 4.99 & 160 \\
\hline Keldsnor $^{\mathrm{a}}$ & NE & EMEP & 54.73 & 10.73 & 10 & Vilsandi $^{\mathrm{a}}$ & NE & EMEP & 58.38 & 21.82 & 6 \\
\hline Kollumerwaard $^{\mathrm{a}, \mathrm{b}, \mathrm{c}}$ & KOW/NE & GAW/EMEP & 53.33 & 6.28 & 1 & Vindeln $^{\mathrm{a}}$ & VIN/NE & GAW/EMEP & 64.25 & 19.77 & 225 \\
\hline Koŝetice ${ }^{a, b, c}$ & $\mathrm{KOS} / \mathbf{C E}$ & GAW/EMEP & 49.58 & 15.08 & 534 & Virolahti II ${ }^{\mathrm{a}}$ & NE & EMEP & 60.53 & 27.69 & 4 \\
\hline Kovk $^{\mathrm{a}}$ & $\mathrm{KOV} / \mathbf{C E}$ & GAW/EMEP & 46.12 & 15.11 & 600 & Vorhegg $^{\mathrm{a}}$ & CE & EMEP & 46.68 & 12.97 & 1020 \\
\hline K-puszta ${ }^{a}$ & CE & EMEP & 46.97 & 19.58 & 125 & Vredepeel $^{\mathrm{a}}$ & NE & EMEP & 51.54 & 5.85 & 28 \\
\hline Krvavec $^{\mathrm{a}, \mathrm{b}}$ & $\mathrm{KRV} / \mathrm{CE}$ & GAW/EMEP & 46.30 & 14.54 & 1740 & Waldhof $^{\mathrm{a}}$ & WAL/NE & GAW/EMEP & 52.80 & 10.77 & 74 \\
\hline La Coulonche ${ }^{\mathrm{a}}$ & CE & EMEP & 48.63 & -0.45 & 309 & Westerland $^{\mathrm{a}}$ & WES/NE & GAW/EMEP & 54.93 & 8.32 & 12 \\
\hline La Tardière $^{\mathrm{a}}$ & CE & EMEP & 46.65 & -0.75 & 143 & Weybourne $^{\mathrm{a}}$ & NE & EMEP & 52.95 & 1.12 & 16 \\
\hline Lac La Biche ${ }^{b}$ & LAC & GAW & 54.95 & -112.45 & 540 & Wicken Fen ${ }^{\mathrm{a}}$ & NE & EMEP & 52.30 & -0.29 & 5 \\
\hline Ladybower Res. $^{\mathrm{a}}$ & NE & EMEP & 53.40 & -1.75 & 420 & Yarner Wood $^{\mathrm{a}}$ & NE & EMEP & 50.59 & -3.71 & 119 \\
\hline Lahemaa $^{\mathrm{a}}$ & NE & EMEP & 59.50 & 25.90 & 32 & Yonagunijima $^{\mathrm{a}, \mathrm{b}}$ & YON & GAW & 24.47 & 123.02 & 30 \\
\hline Lauder $^{\mathrm{a}}$ & LAU & GAW & -45.03 & 169.67 & 370 & Zarodnje $^{\mathrm{a}}$ & $\mathbf{C E}$ & EMEP & 46.42 & 15.00 & 770 \\
\hline Le Casset $^{\mathrm{a}}$ & $\mathbf{C E}$ & EMEP & 45.00 & 6.47 & 750 & Zarra $^{a}$ & SE & EMEP & 39.09 & -1.10 & 885 \\
\hline $\mathrm{Leba}^{\mathrm{a}}$ & NE & EMEP & 54.75 & 17.53 & 2 & Zavodnje $^{\mathrm{a}}$ & $\mathrm{ZAV}$ & GAW & 46.43 & 15.00 & 770 \\
\hline Lerwick $^{\mathrm{a}}$ & NE & EMEP & 60.13 & -1.18 & 85 & Zillertaler Alpen $^{\mathrm{a}}$ & $\mathrm{CE}$ & EMEP & 47.14 & 11.87 & 1970 \\
\hline Lille Valby ${ }^{a}$ & NE & EMEP & 55.69 & 12.13 & 10 & Zingst $^{\mathrm{a}}$ & ZIN/NE & GAW/EMEP & 54.43 & 12.73 & 1 \\
\hline Lough Navar ${ }^{\mathrm{a}}$ & NE & EMEP & 54.44 & -7.87 & 126 & Zoebelboden $^{\mathrm{a}}$ & CE & EMEP & 47.83 & 14.44 & 899 \\
\hline
\end{tabular}

global coverage within 3 days. The data used in this study correspond to $\mathrm{CO}$ total columns from version 5 (V5) of the MOPITT thermal infrared (TIR) product level 3. This product is available via the following web server: http://www2. acd.ucar.edu/mopitt/products. Validation of the MOPITT V5 product against in situ $\mathrm{CO}$ observations shows a mean bias of $0.06 \times 10^{18}$ molecules $\mathrm{cm}^{-2}$ (Deeter et al., 2013). Following the recommendation in the users' guide (www.acd.ucar. edu/mopitt/v5_users_guide_beta.pdf), the MOPITT data are averaged by taking into account their relative errors provided by the observation quality index (OQI).

Also, to achieve better data quality, we use only daytime $\mathrm{CO}$ data since retrieval sensitivity is greater for daytime rather than night-time overpasses. A further description of the V5 data is presented in Deeter et al. (2013) and Worden et al. (2014).

For the validation, the model $\mathrm{CO}$ profiles $(X)$ are transformed by applying the MOPITT averaging kernels $(A)$ and the a priori CO profile $\left(X_{\mathrm{a}}\right)$ according to the following equation (Rodgers, 2000) to derive the smoothed profiles $X^{*}$ appropriate for comparison with MOPITT data:

$X^{*}=X_{\mathrm{a}}+A\left(X-X_{\mathrm{a}}\right)$.
Details on the method of calculation are referred to in Deeter et al. (2004) and Rodgers (2000). The averaging kernels indicate the sensitivity of the MOPITT measurement and retrieval system to the true $\mathrm{CO}$ profile, with the remainder of the information set by the a priori profile and retrieval constraints (Emmons, 2009; Deeter et al., 2010). The CO data $X^{*}$ (derived using the above equation) have the same vertical resolution and a priori dependence as the MOPITT retrievals and have been used to calculate averaging kernel smoothed model CO total columns, which are compared to the MOPITT CO total columns. For the validation, eight regions are defined (see Fig. 1): Europe, Alaska, Siberia, North Africa, southern Africa, South Asia, East Asia and the United States.

The model update in July 2012 includes an integration of MOPITT CO total columns in the model's data assimilation system. With this, the MOPITT validation data have lost their independency for the rest of the validation period and MOPITT validation data have thus only been used until June 2012 for validation purposes. 


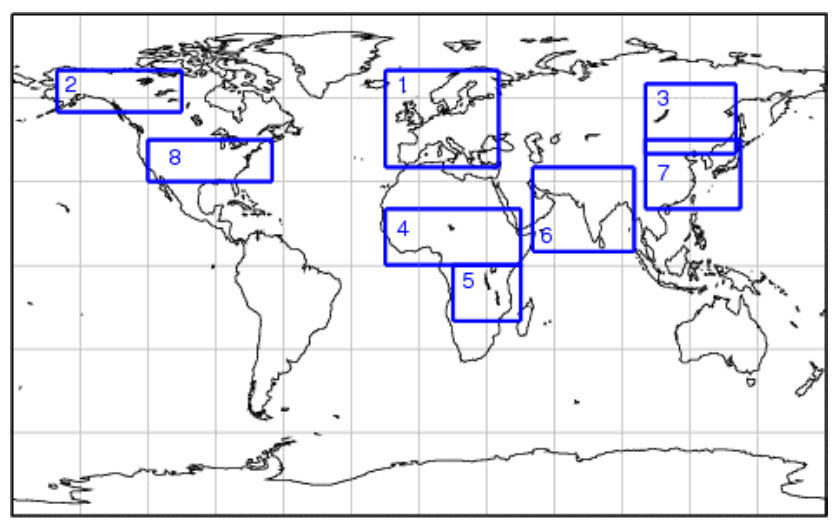

Figure 1. Regions used for regional data stratification in the troposphere for the comparison with satellite data. The following regions are defined: 1: Europe $\left(15^{\circ} \mathrm{W}-35^{\circ} \mathrm{E}, 35-70^{\circ} \mathrm{N}\right)$; 2: Alaska $\left(150-105^{\circ} \mathrm{W}, 55-70^{\circ} \mathrm{N}\right)$; 3: Siberia $\left(100-140^{\circ} \mathrm{E}, 40-65^{\circ} \mathrm{N}\right)$; 4: North Africa $\left(15^{\circ} \mathrm{W}-45^{\circ} \mathrm{E}, 0-20^{\circ} \mathrm{N}\right)$; 5: southern Africa $(15-$ $45^{\circ}$ E, 20- $\left.0^{\circ} \mathrm{S}\right)$; 6: South Asia $\left(50-95^{\circ}\right.$ E, 5-35 $\left.\mathrm{N}\right)$; 7: East Asia $\left(100-142^{\circ}\right.$ E, $\left.20-45^{\circ} \mathrm{N}\right)$; 8: United States $\left(120-65^{\circ} \mathrm{W}, 30-45^{\circ} \mathrm{N}\right)$.

\subsubsection{SCIAMACHY and GOME-2 $\mathrm{NO}_{2}$ satellite observations}

The SCIAMACHY (Bovensmann et al., 1999) onboard the Envisat and the GOME-2 (Callies et al., 2000) onboard the Meteorological Operational Satellite-A (MetOp-A) comprise UV-VIS (ultraviolet-visible) and NIR (near-infrared) sensors designed to provide global observations of atmospheric trace gases.

In this study, the tropospheric $\mathrm{NO}_{2}$ column data set described in Hilboll et al. (2013a) has been used. The measured radiances are analysed using differential optical absorption spectroscopy (DOAS) (Platt and Stutz, 2008) in the 425$450 \mathrm{~nm}$ wavelength window (Richter and Burrows, 2002; Richter et al., 2011). The influence of stratospheric $\mathrm{NO}_{2}$ air masses has been accounted for using the algorithm detailed by Hilboll et al. (2013b), using stratospheric $\mathrm{NO}_{2}$ fields from the Bremen 3D chemistry and transport model (B3dCTM; see also Sinnhuber et al., 2003a, b; Winkler et al., 2008). Tropospheric air mass factors have been calculated with the radiative transfer model SCIATRAN 2.0 (Rozanov et al., 2005). Only measurements with Fast REtrieval Scheme for Cloud from Oxygen A band (FRESCO+) algorithm (Wang et al., 2008) cloud fractions of less than $20 \%$ are used.

Tropospheric $\mathrm{NO}_{2}$ vertical column density (VCD) from the MACC_osuite is compared to tropospheric $\mathrm{NO}_{2} \mathrm{VCD}$ from GOME-2 and SCIAMACHY. As the European Space Agency lost contact with Envisat in April 2012, GOME-2 data are used for model validation from 1 April 2012 onwards, while SCIAMACHY data are used for the remaining time period (September 2009 to March 2012). Satellite observations are gridded to the horizontal model resolution, i.e. $1.875^{\circ}$ for IFS cycle CY36R1 (September 2009-June 2012) and $1.125^{\circ}$ for cycle CY37R3 (July-December 2012).

A few processing steps are applied to the MACC_osuite data to account for differences with the satellite data such as observation time. First, tropospheric $\mathrm{NO}_{2}$ VCDs are calculated from the model data by vertical integration from the ground up to the height of the tropopause. The latter is derived based on National Centers for Environmental Prediction (NCEP) reanalysis (Kalnay et al., 1996) climatological tropopause pressure shown in Fig. 1 of Santer et al. (2003). Second, simulations are interpolated linearly in time to the SCIAMACHY Equator crossing time (roughly 10:00 LT). This most likely leads to some minor overestimation of model $\mathrm{NO}_{2}$ VCDs compared to GOME-2 data, as the Equator crossing time for GOME-2 is about 09:30 LT. Moreover, only model data for which corresponding satellite observations exist are considered. For the validation, the same regions have been used as for MOPITT (Fig. 1), except for Siberia and Alaska. In contrast to comparisons of MOPITT and model data of $\mathrm{CO}$, no averaging kernels were applied to the model $\mathrm{NO}_{2}$ data.

Satellite observations of tropospheric $\mathrm{NO}_{2}$ columns have relatively large uncertainties, mainly linked to errors in the stratospheric correction method, i.e. in stratospheric $\mathrm{NO}_{2}$ columns (important over clean regions and at high latitudes in winter and spring) and to uncertainties in air mass factors (mainly over polluted regions) (e.g. Boersma et al., 2004; Richter et al., 2005). The uncertainty varies with geolocation and time but in first approximation can be separated into an absolute error of $5 \times 10^{14}$ molec cm$~^{-2}$ and a relative error of about $30 \%$. As some of the contributions to this uncertainty can have systematic causes (e.g. a systematic error in the assumed aerosol load can lead to seemingly random errors in the retrieved $\mathrm{NO}_{2}$ columns due to the complexities of atmospheric radiative transfer, i.e. relative positions of absorber and aerosol layers), averaging over longer time periods does not reduce the errors as much as one would expect for purely random errors. Over polluted regions, the uncertainty from random noise in the spectra is small in comparison to other error sources, in particular for monthly averages.

\subsection{Validation metrics}

A comprehensive model validation requires the selection of validation metrics that provide complementary aspects of model performance. The following metrics have been used in the validation:

Modified normalised mean bias (MNMB)

$\mathrm{MNMB}=\frac{2}{N} \sum_{i} \frac{f_{i}-o_{i}}{f_{i}+o_{i}}$

Root mean square error (RMSE)

$\left.\operatorname{RMSE}=\sqrt{\frac{1}{N} \sum_{i}\left(f_{i}\right.}-o_{i}\right)^{2}$ 
Correlation coefficient

$$
R=\frac{\frac{1}{N} \sum_{i}\left(f_{i}-\bar{f}\right)\left(o_{i}-\bar{o}\right)}{\sigma_{f} \sigma_{o}},
$$

where $N$ is the number of observations, $f$ the modelled analysis and $o$ the observed values, $\bar{f}$ and $\bar{o}$ are the mean values of the analysis and observed values and $\sigma_{f}$ and $\sigma_{o}$ the corresponding standard deviations.

The validation metrics above have been chosen to provide complementary aspects of model performance. The modified normalised mean bias is a normalisation based on the mean of the observed and forecast value (e.g. Elguindi et al., 2010). It ranges between -2 and 2 and when multiplied by $100 \%$, it can be interpreted as a percentage bias.

We chose to use the modified normalised mean bias (MNMB) in our evaluations because verifying chemical species concentration values significantly differs from verifying standard meteorological fields. For example, spatial or temporal variations can be much greater and the differences between model and observed values ("model errors") are frequently much larger in magnitude. Most importantly, typical concentrations can vary quite widely between different pollutant types (e.g. $\mathrm{O}_{3}$ and $\mathrm{CO}$ ) and regions (e.g. Europe vs. Antarctica), and a given bias or error value can have a quite different significance. It is useful, therefore, to consider bias and error metrics that are normalised with respect to observed concentrations and hence can provide a consistent scale regardless of pollutant type (see e.g. Elguindi et al., 2010, or Savage et al., 2013). Moreover, the MNMB is robust to outliers and converges to the normal bias for biases approaching zero, while taking into account the representativeness issue when comparing coarse-resolved global models versus site-specific station observations. Though GAW stations prove regionally representative in general, the experience is that local effects cannot always be ruled out reliably in long worldwide data sets, because each of the different species has its individual scale of transport and chemical processes, which in one case may exceed and in the other case fall bellow the model resolution. Referencing to the model/observation mean again constitutes a pragmatic solution to avoid misleading bias tendencies, particularly in sensitive regions with sparse data coverage. Within MACC, the MNMB is used as an important standard score. It is used in the MACC quarterly validation reports and it appears in many recent publications, e.g. Cuevas et al. (2015), Eskes et al. (2015), Sheel et al. (2014).

The MNMB varies symmetrically with respect to underand overestimation. However, when calculated over longer time periods, a balance in model error, with model over- and underestimation compensating each other, can lead to a small MNMB for the overall period. For this reason, it is important to additionally consider an absolute measure, such as the root mean square error (RMSE). However, it has to be noted that the RMSE is strongly influenced by larger values and out-
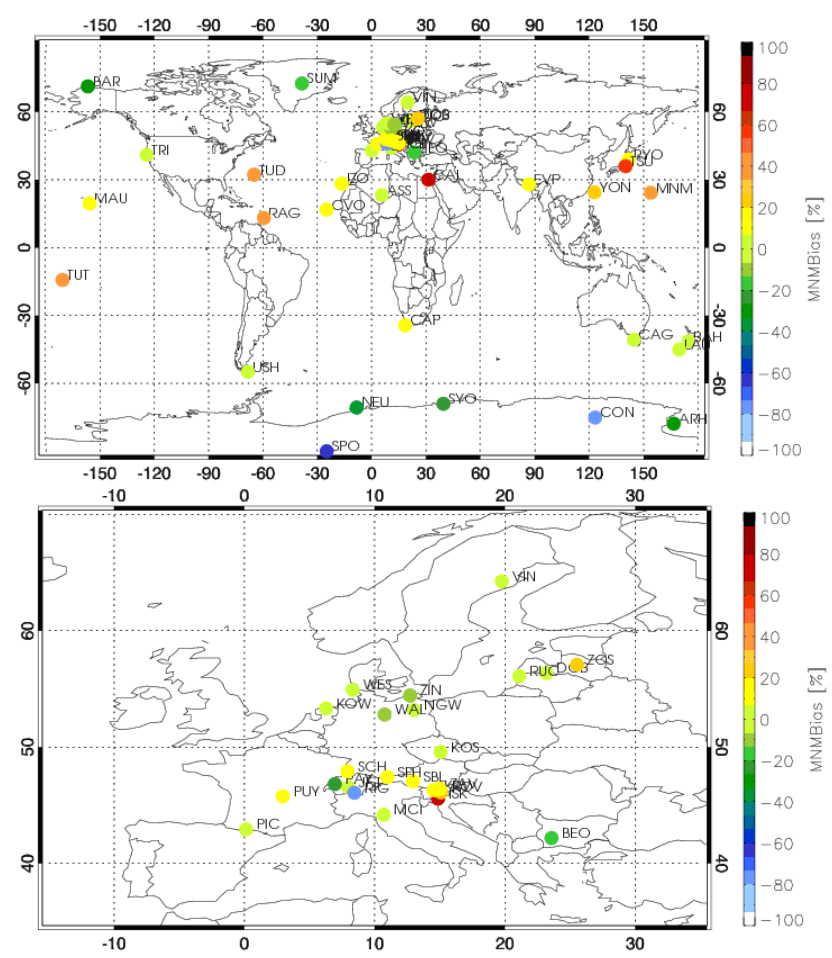

Figure 2. Modified normalised mean biases (MNMBs) [\%] derived from the evaluation of the MACC_osuite with $\mathrm{GAW} \mathrm{O}_{3}$ surface observations during the period September 2009 to December 2012 globally (top), and for Europe (bottom). Blue colours represent large negative values and red/brown colours represent large positive values.

liers, due to squaring. The correlation coefficient $R$ can vary between 1 (perfect correlation) and -1 (perfect negative correlation) and is an important measure for checking the linearity between model and observations.

\section{Results}

\subsection{Validation of ozone}

The evaluation of the MACC_osuite run with $\mathrm{O}_{3}$ from GAW surface observations (described in Sect. 2.2.1) demonstrates good agreement in absolute values and seasonality for most regions. Figure 2 shows maps with MNMB (see Sect. 2.3) evaluations for 50 GAW stations globally (top) and in Europe (bottom). Figure 3 presents selected time series plots representing the results for high latitudes, low latitudes and Europe. Large negative MNMBs over the whole period September 2009 to December 2012 (-30 to -82\%) are observed for stations located in Antarctica (Neumayer (NEU), South Pole (SPO), Syowa (SYO) and Concordia (CON)) whereby $\mathrm{O}_{3}$ surface mixing ratios are strongly underestimated by the model. For stations located at high latitudes in the Northern Hemisphere (Barrow (BAR), Alaska, and Sum- 

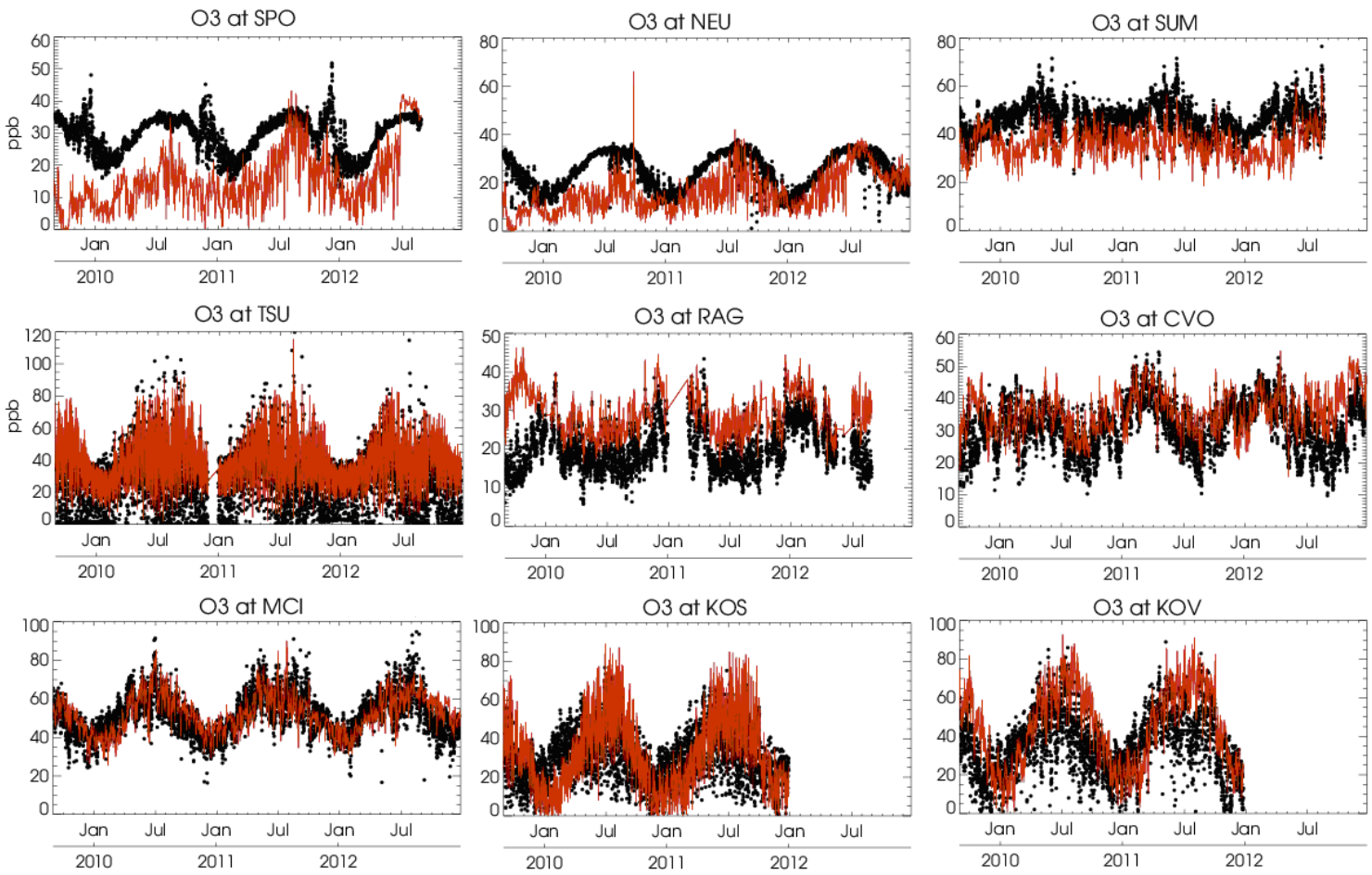

Figure 3. Time series plots of the MACC_osuite 6-hourly $\mathrm{O}_{3}$ mixing ratios (red) and GAW surface observations (black) for South Pole, SPO (Antarctica); Neumayer, NEU (Antarctica); Summit, SUM (Denmark); Tsukuba, TSU (Japan); Ragged Point, RAG (Barbados); Cape Verde Observatory, CVO (Cape Verde); Monte Cimone, MCI (Italy); Kosetice, KOS (Czech Republic); and Kovk, KOV (Slovenia) during the period September 2009 to December 2012. Unit: ppb.

mit (SUM), Denmark), the MACC_osuite exhibits similar underestimated values of up to $-35 \%$ for the whole evaluation period. The time series plots for Arctic and Antarctic stations (e.g. SUM, NEU and SPO) in Fig. 3 show that an underestimation seen in these regions appears to be remedied and model performance improved with an updated dry deposition parameterisation over ice, which has been introduced with the new model cycle in July 2012 (see Sect. 2.1).

Large positive MNMBs (up to 50 to $70 \%$, Fig. 2) are observed for stations that are located in or nearby cities and thus exposed to regional sources of contamination (Iskrba (ISK), Slovenia; Tsukuba (TSU), Japan; Cairo (CAI), Egypt). In tropical and subtropical regions, $\mathrm{O}_{3}$ surface mixing ratios are systematically overestimated (by about $20 \%$ on average) during the evaluation period. The time series plots for tropical and subtropical stations (e.g. for Ragged Point (RAG), Barbados, and Cape Verde Observatory, Cape Verde (CVO), Fig. 3) reveal a slight systematic positive offset throughout the year, however with high correlation coefficients $(0.6$ on average).

For GAW stations in Europe, the evaluation of the MACC_osuite for the whole period shows MNMBs between -80 and $67 \%$. Large biases appear only for two GAW stations located in Europe: Rigi (RIG), Switzerland (-80\%), located near mountainous terrain and ISK, Slovenia (67\%).
For the rest of the stations MNMBs lie between 22 and $-30 \%$. RMSEs (see Sect. 2.3) range between 7 and $35 \mathrm{ppb}$ (15 ppb on average). Again, results for ISK and RIG show the largest errors. All other stations show RMSEs between 7 and $20 \mathrm{ppb}$. Correlation coefficients here range between 0.1 and 0.7 (with 0.5 on average). Table 4 summarises the results for all stations individually.

Monthly MNMBs (see Fig. 4) show a seasonally varying bias, with positive MNMBs occurring during the northern summer months (with global average ranging between 5 and $29 \%$ during the months June and October), and negative MNMBs during the northern winter months (between -2 and $-33 \%$ during the months December to March). These deviations partly cancel each other out in MNMB for the whole evaluation period. For the RMSEs (Fig. 5) maximum values also occur during the northern summer months with the global average ranging between 11 and $16 \mathrm{ppb}$ for June to September. The smallest errors appear during the northern hemispheric winter months (global average falling between 8 and $10 \mathrm{ppb}$ for December and January). The correlation does not show a distinct seasonal behaviour (see Fig. 6).

The time series plots in Fig. 3 show that the seasonal cycle of $\mathrm{O}_{3}$ mixing ratios with maximum concentrations during the summer months and minimum values occurring during winter times for European stations (e.g. Monte Cimone 
Table 4. Modified normalised mean bias (MNMB) [\%], correlation coefficient $(R)$, and root mean square error (RMSE) [ppb] derived from the evaluation of the MACC_osuite with Global Atmosphere Watch (GAW) $\mathrm{O}_{3}$ surface observations during the period September 2009 to December 2012. The conventional station names are listed in Table 3.

\begin{tabular}{|c|c|c|c|c|c|c|c|c|c|c|c|c|c|c|c|c|c|}
\hline Station & $\mathrm{ARH}$ & ASS & BAH & BAR & BEO & CAI & CAG & CAP & $\mathrm{CVO}$ & $\mathrm{CON}$ & DOB & EVP & ISK & IZO & JFJ & KOW & KOS \\
\hline MNMB & -39.8 & -6.3 & -8.6 & -35.1 & -21.4 & 70.1 & -12.7 & 13.7 & 15.2 & -81.6 & 6.3 & 18.4 & 67.2 & 10.4 & 1.9 & 5.8 & -5.9 \\
\hline$R$ & 0.6 & 0.7 & 0.5 & 0.3 & 0.4 & -0.1 & 0.4 & 0.6 & 0.6 & 0.3 & 0.3 & 0.7 & 0.1 & 0.5 & 0.7 & 0.6 & 0.6 \\
\hline RMSE & 10.6 & 6.5 & 8.0 & 13.8 & 20.4 & 29.2 & 8.9 & 7.6 & 8.0 & 17.2 & 14.3 & 12.0 & 34.5 & 10.8 & 7.4 & 12.0 & 16.3 \\
\hline Station & KOV & KRV & LAU & MAU & MNM & MCI & NGW & NEU & PAY & PIC & PUY & RAG & RIG & RUC & RYO & $\mathrm{SCH}$ & SBL \\
\hline MNMB & 21.2 & 9.5 & -5.5 & 13.7 & 38.6 & 2.3 & -11.4 & -45.2 & -28.8 & 5.5 & 12.8 & 38.6 & -80.3 & -0.1 & 10.5 & 8.5 & 8.1 \\
\hline$R$ & 0.6 & 0.6 & 0.5 & 0.6 & 0.8 & 0.7 & 0.5 & 0.5 & 0.7 & 0.6 & 0.6 & 0.6 & 0.3 & 0.3 & 0.1 & 0.7 & 0.6 \\
\hline RMSE & 19.5 & 11.1 & 9.0 & 11.5 & 13.0 & 8.2 & 14.3 & 11.4 & 15.6 & 7.7 & 10.6 & 10.6 & 28.4 & 15.0 & 14.4 & 12.2 & 9.3 \\
\hline Station & SFH & SPO & SUM & SYO & TRI & TSU & TUD & TUT & USH & VIN & WAL & WES & YON & ZAV & $\mathrm{ZIN}$ & ZOS & \\
\hline MNMB & 10.1 & -70.6 & -24.4 & -31.2 & 3.2 & 55.1 & 45.3 & 40.2 & -7.0 & 4.6 & -18.0 & -12.3 & 22.0 & 19.7 & -17.5 & 22.3 & \\
\hline$R$ & 0.6 & 0.4 & 0.5 & 0.7 & 0.3 & 0.0 & 0.5 & 0.8 & 0.5 & 0.4 & 0.6 & 0.6 & 0.7 & 0.6 & 0.4 & 0.2 & \\
\hline RMSE & 9.3 & 16.3 & 11.7 & 8.9 & 13.3 & 27.6 & 18.2 & 8.0 & 7.6 & 11.2 & 13.6 & 11.6 & 13.6 & 18.6 & 13.9 & 17.0 & \\
\hline
\end{tabular}

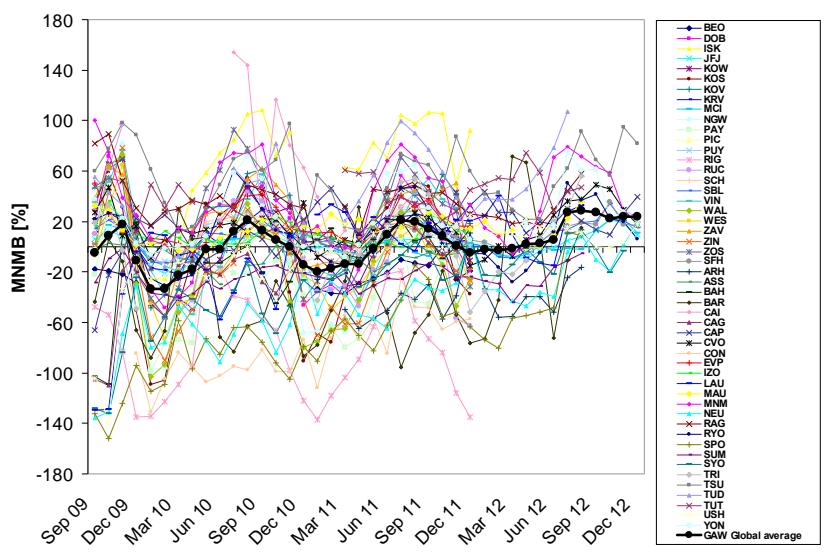

Month

Figure 4. Modified normalised mean bias (MNMB) in \% derived from the evaluation of the MACC_osuite with GAW $\mathrm{O}_{3}$ surface observations during the period September 2009 to December 2012 (black line: global average of $50 \mathrm{GAW}$ stations. Multi-coloured lines: individual station results; see legend to the right).

(MCI), Italy; Kosetice (KOS), Czech Republic; and Kovk (KOV), Slovenia), could be well reproduced by the model, although there is some overestimation in summer resulting mostly from observed minimum concentrations that are not captured correctly by the MACC_ osuite (KOS, Czech Republic, and KOV, Slovenia).

The validation with EMEP surface ozone observations (described in Sect. 2.2.2) in three different regions in Europe for the period September 2009 to December 2012 likewise confirms the behaviour of the model to overestimate $\mathrm{O}_{3}$ mixing ratios during the warm period and underestimate $\mathrm{O}_{3}$ concentrations during the cold period of the year (see Fig. 7). The mostly positive bias (May-November) is between -9 and $56 \%$ for northern Europe and central Europe and between 8 and $48 \%$ for southern Europe. Negative MNMBs appear, in accordance with GAW validation results, during

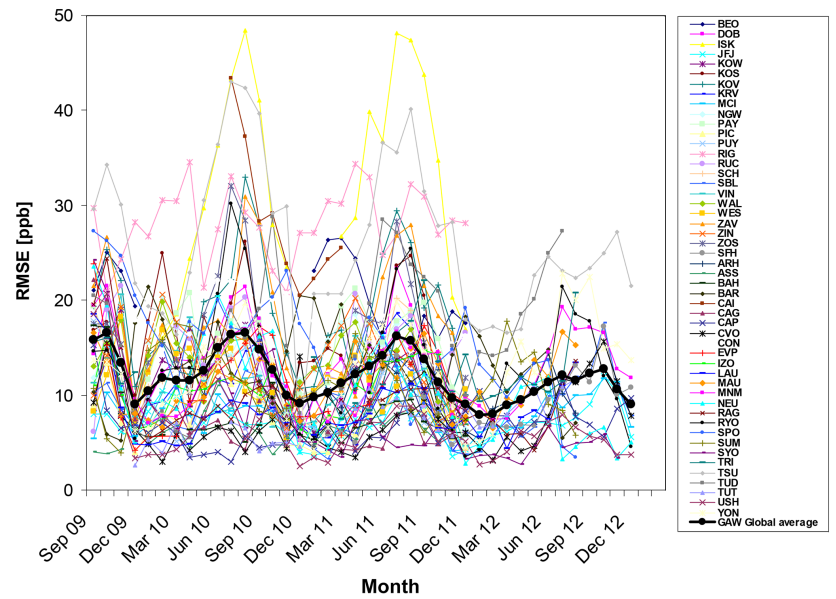

Figure 5. Root mean square error (RMSE) in ppb derived from the evaluation of the MACC_osuite with GAW $\mathrm{O}_{3}$ surface observations during the period September 2009 to December 2012 (black line: global average of 50 GAW stations. Multi-coloured lines: individual station results; see legend to the right).

the winter-spring period (December-April) ranging between -48 and $-7 \%$ for EMEP stations in northern Europe (exception: December 2012 with $25 \%$ ), between -1 and $-39 \%$ in central Europe (exception: December 2012 with $31 \%$ ), whereas in southern Europe, deviations are smaller and remain mostly positive (between -8 and $9 \%$ ) in winter (exception: December 2012 with $37 \%$ ). The different behaviour for December 2012 likely results from the limited availability of observations towards the end of the validation period. The separate evaluation of day and night-time $\mathrm{O}_{3}$ mixing ratios (Fig. 8) shows that for northern Europe night-time biases exceed daytime biases during all seasons. For central Europe and southern Europe night-time biases are larger (negative MNMBs) during cold periods (December-April), whereas during warm periods (May-November) larger biases (positive MNMBs) appear during daytime. 
Table 5. Modified normalised mean bias (MNMB) [\%], correlation coefficient $(R)$, and root mean square error (RMSE) [ppb] derived from the evaluation of the MACC_osuite with Global Atmospheric Watch (GAW) CO surface observations during the period September 2009 to December 2012. The conventional station names are listed in Table 3.

\begin{tabular}{|c|c|c|c|c|c|c|c|c|c|c|c|c|c|c|c|c|c|}
\hline Station & ALT & BEO & CAP & $\mathrm{CHI}$ & $\mathrm{CVO}$ & EGB & ESP & ETL & FRA & IZO & JFJ & KOS & KOW & KRV & LAC & MCI & MNM \\
\hline MNMB & -6.9 & -36.1 & 29.7 & -7.3 & -0.6 & 4.5 & -1.7 & -19.9 & -12.0 & -6.8 & -15.1 & -50.1 & -5.9 & -30.4 & -24.2 & -19.0 & 6.4 \\
\hline$R$ & 0.5 & 0.0 & 0.6 & 0.4 & 0.7 & 0.3 & 0.5 & 0.1 & 0.3 & 0.7 & 0.6 & 0.2 & 0.4 & 0.4 & 0.0 & 0.6 & 0.8 \\
\hline RMSE & 23.4 & 90.3 & 20.4 & 31.1 & 14.2 & 60.1 & 25.7 & 53.9 & 35.9 & 15.3 & 25.8 & 131.1 & 70.1 & 49.1 & 58.5 & 32.0 & 22.0 \\
\hline Station & NGW & PAY & PIC & PUY & RIG & RYO & SAB & SBL & $\mathrm{SCH}$ & SFH & USH & YON & & & & & \\
\hline MNMB & -1.7 & -7.3 & -9.3 & -10.4 & 28.2 & -4.8 & -8.1 & -25.1 & -15.8 & -25.7 & -9.1 & -1.6 & & & & & \\
\hline$R$ & 0.4 & 0.3 & 0.7 & 0.6 & 0.0 & 0.4 & 0.4 & 0.5 & 0.5 & 0.4 & 0.6 & 0.7 & & & & & \\
\hline RMSE & 61.6 & 99.2 & 18.4 & 30.6 & 143.5 & 44.5 & 31.6 & 36.8 & 39.8 & 45.0 & 12.3 & 62.3 & & & & & \\
\hline
\end{tabular}

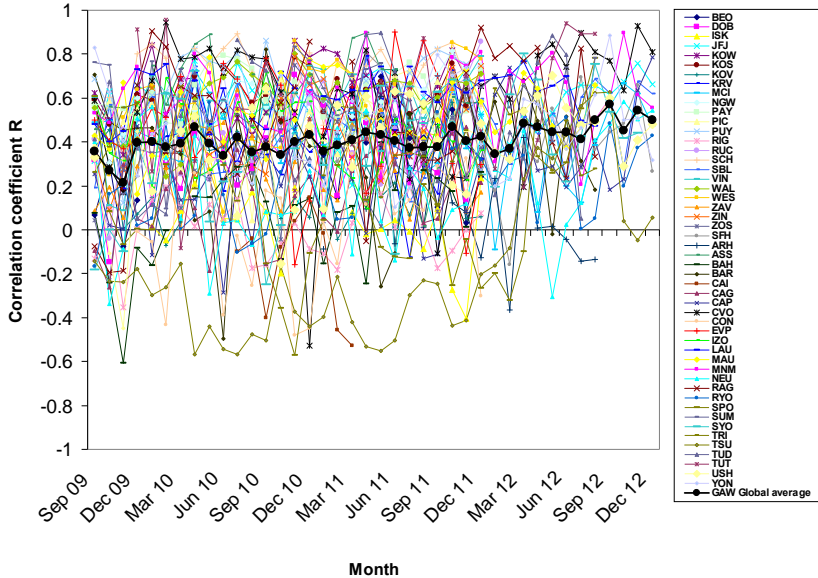

Figure 6. Correlation coefficient $(R)$, derived from the evaluation of the MACC_osuite with $\mathrm{GAW} \mathrm{O}_{3}$ surface observations during the period September 2009 to December 2012 (black line: global average of $50 \mathrm{GAW}$ stations. Multi-coloured lines: individual station results; see legend to the right).

\subsection{Validation of carbon monoxide}

The validation of the MACC_osuite with surface observations of 29 GAW stations (described in Sect. 2.2.1) shows that over the whole period September 2009 to December 2012, CO mixing ratios could be reproduced with an average MNMB of $-10 \%$. The MNMBs for all stations range between -50 and $+30 \%$. Results are listed in Table 5; a selection of time series plots shows the results for stations in Europe, Asia and Canada in Fig. 9. MNMBs exceeding $\pm 30 \%$ appear for stations that are either located in or nearby cities and thus exposed to regional sources of contamination (KOS, Czech Republic) or are located in or near complex mountainous terrain (RIG, Switzerland, and BEO Moussala (BEO), Bulgaria) which is not resolved by the topography of the global model. The RMSEs fall between 12 and $143 \mathrm{ppb}$ (on average $48 \mathrm{ppb}$ ) for all stations during the validation period, but for only four stations (RIG, KOS, Payerne (PAY), Switzerland and BEO, all located in Europe) do the RMSEs exceed $70 \mathrm{ppb}$. Correlation coefficients from the comparison

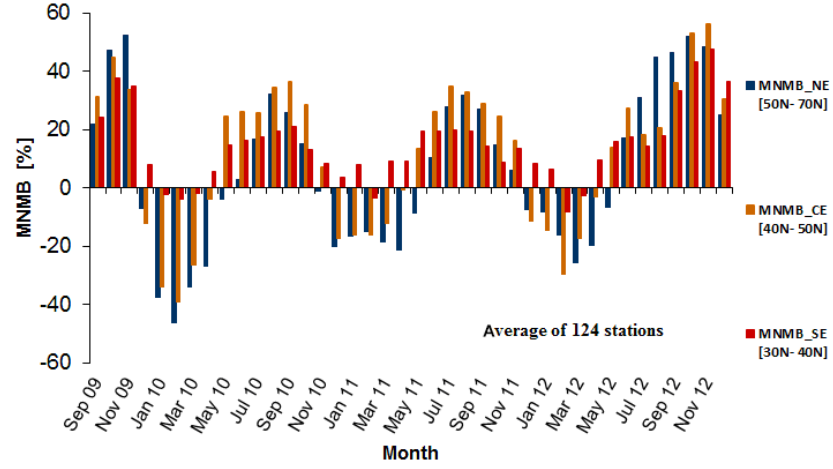

Figure 7. Modified normalised mean biases (MNMBs in \%) derived from the evaluation of the MACC_osuite with EMEP $\mathrm{O}_{3}$ surface observations in three different parts in Europe (blue: northern Europe, orange: central Europe, red: southern Europe) during the period September 2009 to December 2012.

with GAW station data calculated over the whole time period range between 0 and 0.8 (on average 0.4 ), with only four stations showing values smaller than 0.2 (RIG, BEO, East Trout Lake (ETL) and Lac la Biche (LAC); the latter two located in Canada).

Considering the global monthly MNMBs and RMSEs, it can be seen that during the northern hemispheric summer months, June to September, both are small (absolute differences less than $5 \%$ ); see Figs. 10 and 11 . Negative MNMBs (up to $-35 \%$ ) and larger RMSEs (up to $72 \mathrm{ppb}$ ) appear during the northern hemispheric winter months, November to March, when anthropogenic emissions are at a highest level, especially for the US, northern latitudes and Europe. Monthly correlation coefficients are between 0.1 and 0.5 and do not show a distinct seasonal behaviour (see Fig. 12), the low values of 0.1 during the period January to October 2011 result from the reading error in the fire emissions (see Sect. "Emission inventories and assimilated data sets"). The generally only moderate correlation coefficient is related to mismatches in the strong short-term variability seen in both the model and the measurements.

The time series plots for stations in Europe, Asia and Canada in Fig. 9 demonstrate that the annual CO cycle could 

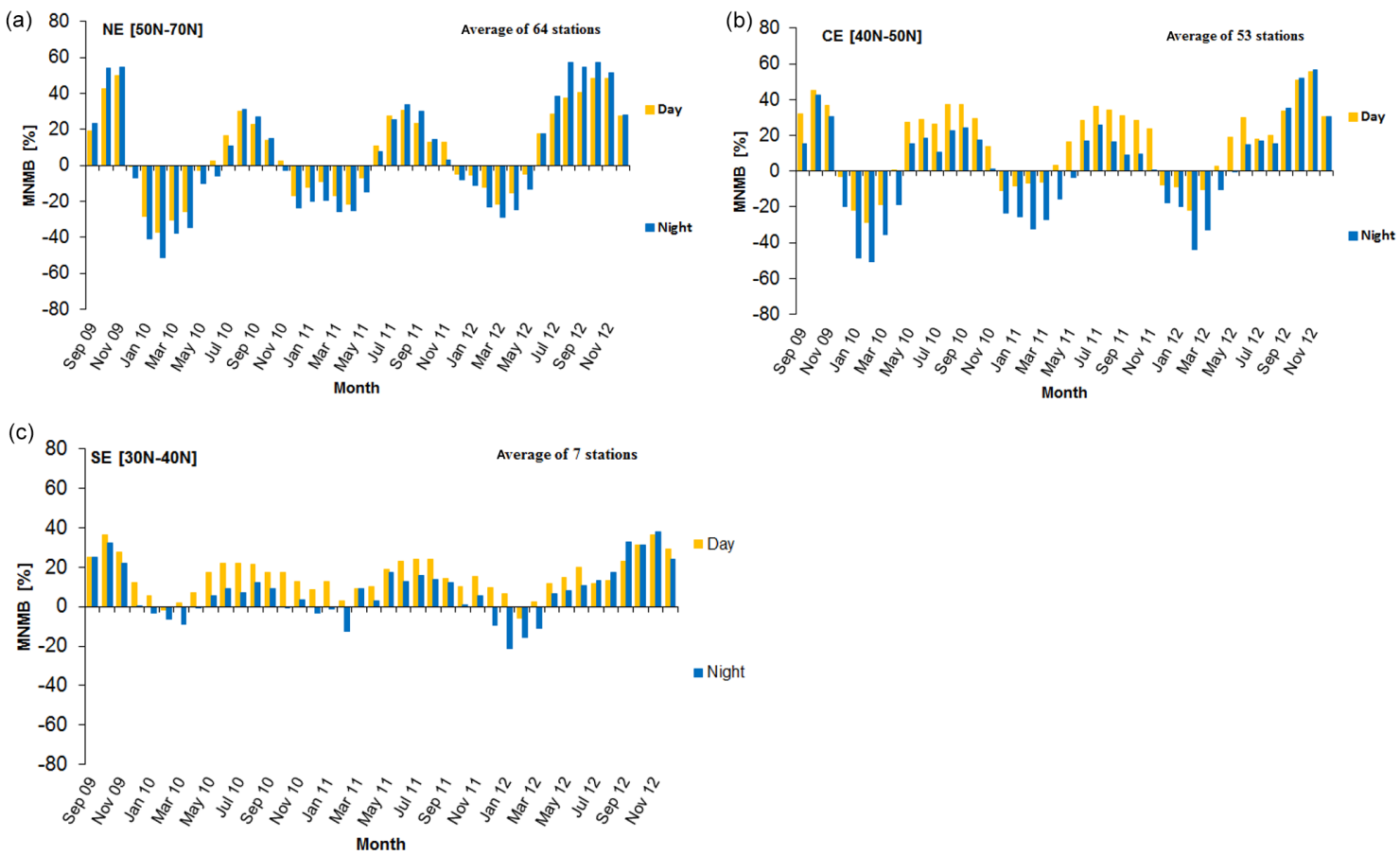

Figure 8. Modified normalised mean biases (MNMBs in \%) derived from the evaluation of the MACC_osuite with EMEP $\mathrm{O}_{3}$ surface observations during daytime (yellow colour), and night-time (blue colour) over northern Europe (a), central Europe (b) and southern Europe (c) during the period September 2009 to December 2012.
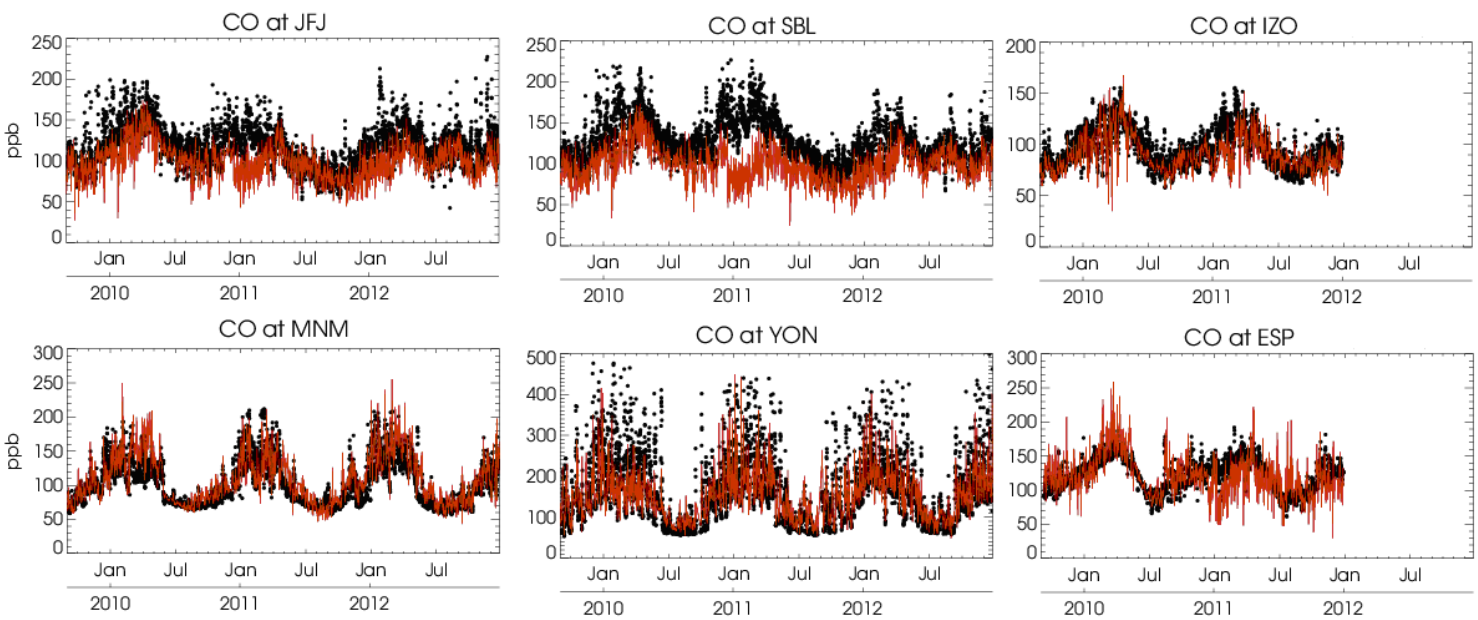

Figure 9. Time series plots of the MACC_osuite 6-hourly CO mixing ratios (red) and GAW surface observations (black) for Jungfraujoch, JFJ (Switzerland); Sonnblick, SBL (Austria); Izana Observatory, IZO (Tenerife); Minamitorishima, MNM (Japan); Yonagunijima, YON (Japan); and Estevan Point, EVP (Canada) during the period September 2009 to December 2012. Unit: ppb.

to a large degree be reproduced correctly by the model with maximum values occurring during the winter period and minimum values appearing during the summer season. However, the model shows a negative offset during the winter period. Seasonal air mass transport patterns that lead to regular annual re-occurring $\mathrm{CO}$ variations could be reproduced for GAW stations in East Asia: the time series plots for Yonagunijima (YON) and Minamitorishima (MNM) station, Japan
(Fig. 9), show that the drop of $\mathrm{CO}$, associated with the air mass change from continental to cleaner marine air masses after the onset of the monsoon season during the early summer months, is captured by the MACC_osuite. Deterioration in all scores is visible during December 2010 in the time series plots of several stations (e.g. Jungfraujoch (JFJ), and Sonnblick (SBL), Fig. 9). This is likely a result of changes in 
Table 6. Modified normalised mean bias (MNMB) [\%] derived from CO satellite observations (MOPITT) and the MACC_osuite simulations of CO total columns from October 2009 until June 2012 averaged over different regions.

\begin{tabular}{|c|c|c|c|c|c|c|c|c|c|c|c|}
\hline & 9 Oct & $9 \mathrm{Nov}$ & $9 \mathrm{Dec}$ & $10 \mathrm{Jan}$ & $10 \mathrm{Feb}$ & $10 \mathrm{Mar}$ & $10 \mathrm{Apr}$ & 10 May & 10 Jun & $10 \mathrm{Jul}$ & $10 \mathrm{Aug}$ \\
\hline Europe & 4.17 & 1.35 & -7.02 & -7.17 & -7.84 & -8.56 & -5.20 & -2.15 & -2.96 & 0.75 & -2.88 \\
\hline Alaska & 0.31 & -3.16 & -6.71 & -8.85 & -6.39 & -3.13 & -4.49 & -3.85 & -8.69 & -6.18 & -3.94 \\
\hline Siberia & 2.02 & 1.62 & -1.44 & -2.75 & -1.36 & -2.27 & -3.58 & -2.93 & -5.30 & 4.21 & -8.43 \\
\hline N. Africa & 6.53 & 9.17 & 5.82 & 7.05 & 3.45 & -2.96 & -3.53 & -1.75 & -3.40 & -1.21 & -3.58 \\
\hline S. Africa & -12.45 & -9.44 & 3.10 & 6.53 & 8.27 & 6.63 & 3.57 & 2.33 & 7.34 & 0.57 & -2.75 \\
\hline S. Asia & 9.20 & 13.73 & 6.95 & 6.41 & 6.69 & 1.12 & 3.18 & 1.26 & -3.01 & 1.98 & 2.15 \\
\hline E. Asia & 8.04 & 12.33 & -5.86 & -9.18 & -6.64 & -4.49 & -5.12 & -5.61 & -7.72 & -4.34 & -2.80 \\
\hline \multirow[t]{2}{*}{ US } & 9.73 & 6.71 & -5.42 & -7.75 & -10.88 & -6.26 & -3.80 & -2.04 & 1.58 & 2.54 & 2.98 \\
\hline & $10 \mathrm{Sep}$ & $10 \mathrm{Oct}$ & $10 \mathrm{Nov}$ & $10 \mathrm{Dec}$ & 11 Jan & $11 \mathrm{Feb}$ & $11 \mathrm{Mar}$ & $11 \mathrm{Apr}$ & 11 May & 11 Jun & $11 \mathrm{Jul}$ \\
\hline Europe & -1.97 & -0.92 & -2.94 & -7.78 & -15.41 & -17.22 & -18.78 & -17.34 & -13.34 & -6.62 & -3.91 \\
\hline Alaska & -5.00 & -1.89 & -4.87 & -7.51 & -14.54 & -9.90 & -9.29 & -12.54 & -11.95 & -10.04 & -4.73 \\
\hline Siberia & -2.94 & -1.93 & -1.73 & -3.02 & -7.71 & -7.78 & -12.09 & -21.99 & -17.23 & -11.59 & -4.97 \\
\hline N. Africa & -1.22 & 3.33 & 5.98 & 7.03 & -0.53 & 4.31 & 2.66 & 1.37 & 4.23 & 4.71 & 4.37 \\
\hline S. Africa & -5.13 & 2.84 & 7.39 & 4.37 & 1.41 & 3.39 & 3.80 & 0.99 & 5.71 & 3.45 & -2.75 \\
\hline S. Asia & 5.05 & 6.72 & 9.63 & 10.30 & 2.19 & 2.91 & 1.48 & -1.76 & 1.68 & 1.62 & 2.90 \\
\hline E. Asia & 6.13 & 6.93 & 2.44 & 3.23 & -11.25 & -9.18 & -9.63 & -8.58 & -4.73 & -1.62 & 5.00 \\
\hline \multirow[t]{2}{*}{ US } & 0.08 & -0.71 & 1.20 & -8.06 & -18.30 & -16.98 & -14.33 & -13.52 & -8.10 & -4.72 & -0.64 \\
\hline & $11 \mathrm{Aug}$ & $11 \mathrm{Sep}$ & 11 Oct & $11 \mathrm{Nov}$ & $11 \mathrm{Dec}$ & 12 Jan & $12 \mathrm{Feb}$ & $12 \mathrm{Mar}$ & $12 \mathrm{Apr}$ & 12 May & 12 Jun \\
\hline Europe & -2.57 & -7.28 & -10.80 & -11.85 & -14.79 & -13.50 & -14.16 & -15.30 & -11.49 & -7.00 & -3.65 \\
\hline Alaska & -5.69 & -11.86 & -18.05 & -14.33 & -12.29 & -11.50 & -11.24 & -11.92 & -9.42 & -8.71 & -4.74 \\
\hline Siberia & -6.05 & -15.16 & -16.50 & -10.32 & -11.59 & -10.15 & -8.45 & -13.14 & -12.18 & -11.08 & -4.45 \\
\hline N. Africa & 6.15 & 5.35 & 6.27 & -0.93 & 3.37 & 2.04 & 1.11 & -5.90 & -3.40 & -3.59 & -0.95 \\
\hline S. Africa & -6.70 & -4.43 & -0.58 & 3.64 & 4.66 & 4.25 & 2.91 & 0.91 & 3.41 & 1.33 & -1.23 \\
\hline S. Asia & 3.80 & 2.27 & 4.24 & 4.76 & 7.00 & 3.24 & 1.72 & -1.23 & -0.90 & 0.49 & -0.61 \\
\hline E. Asia & 3.05 & 1.60 & -2.60 & -2.48 & -5.15 & -5.56 & -4.63 & -0.85 & -0.36 & -2.63 & 0.68 \\
\hline US & -1.17 & -2.40 & -4.23 & -6.14 & -10.84 & -13.30 & -14.87 & -9.19 & -6.94 & -2.88 & -2.55 \\
\hline
\end{tabular}

the processing of the L2 IASI data and a temporary blacklisting of IASI data (to avoid model failure) in the assimilation.

The comparison with MOPITT satellite CO total columns between October 2009 and June 2012 (described in Sect. 2.2.3) shows a good qualitative agreement of spatial patterns and seasonality; see Table 6. The MNMBs for eight regions are listed in Fig. 13 and range between -22 and $14 \%$. The seasonality of the satellite observations is captured well by the MACC_osuite over Asia and Africa, with MNMBs between -6 and $9 \%$ (North Africa), -12 and $8 \%$ (southern Africa), -11 and $12 \%$ (East Asia) and -3 and $14 \%$ (South Asia). The largest negative MNMBs appear during the winter periods, especially from December 2010 to May 2011 and from September 2011 to April 2012, for Alaska and Siberia and for the US and Europe (MNMBs up to $-22 \%$ ), which coincides with large differences between MOPITT and IASI satellite data (see Fig. 14). On the global scale the average difference between the IASI and MOPITT total columns is less than $10 \%$ (George et al., 2009), and there is a close agreement of MOPITT and IASI for South Asia and Africa (see Fig. 14). However, larger differences between MOPITT and IASI data appear during the north- ern winter months over Alaska, Siberia, Europe and the US, which result in lower $\mathrm{CO}$ concentrations in the model, due to the assimilation of IASI CO data in the MACC_osuite. The differences between MOPITT and IASI data can be mainly explained by the use of different a priori assumptions in the IASI and MOPITT retrieval algorithms (George et al., 2015). The Fast Optimal Retrievals on Layers for IASI (FORLI; Hurtmans et al., 2012) software uses a single a priori $\mathrm{CO}$ profile (with an associated variance-covariance matrix) whereas the MOPITT retrieval algorithm uses a variable a priori, depending on time and location. George et al. (2015) showed that differences above Europe and the US in January and December (for a 6 year study) decrease by a factor of 2 when comparing IASI with a modified MOPITT product using the IASI single a priori. Between January and October 2011 there has also been a reading error in the fire emissions that contributes to larger MNMBs during this period (see Sect. "Emission inventories and assimilated data sets"). 


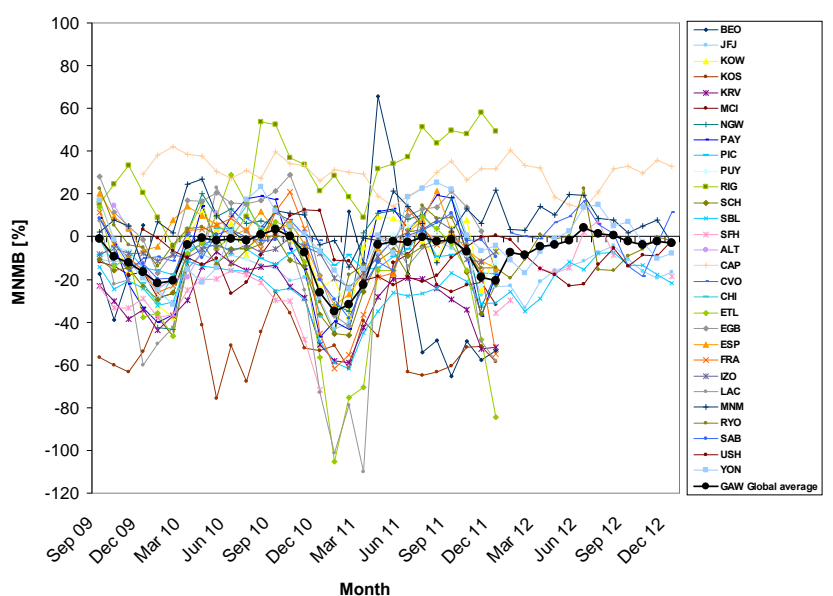

Figure 10. Modified normalised mean bias (MNMB) in \% derived from the evaluation of the MACC_osuite with GAW CO surface observations over the period September 2009 to December 2012 (black line: global average of 29 GAW stations. Multi-coloured lines: individual station results; see legend to the right).

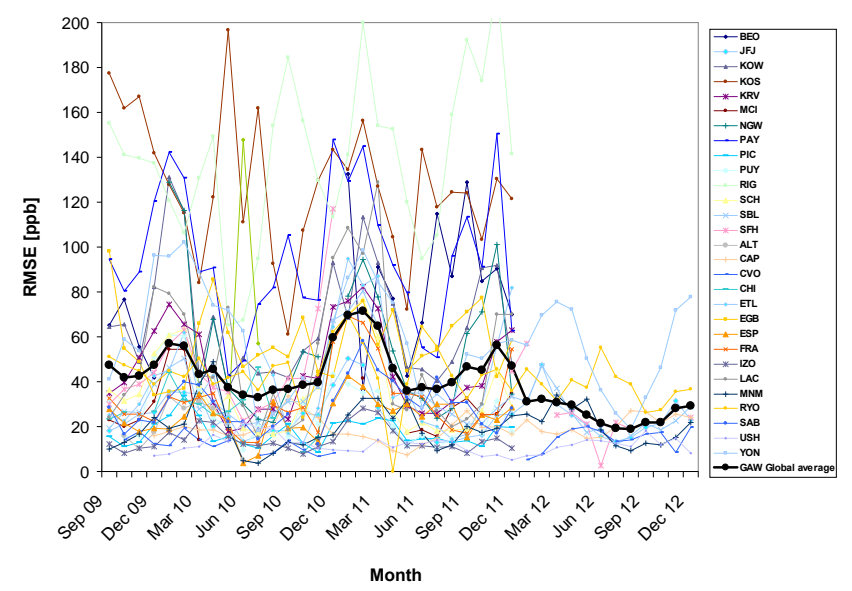

Figure 11. Root mean square error (RMSE) in ppb derived from the evaluation of the MACC_osuite with GAW CO surface observations over the period September 2009 to December 2012 (black line: global average of 29 GAW stations multi-coloured lines: individual station results; see legend to the right).

\subsection{Validation of tropospheric nitrogen dioxide}

Figure 15 shows global maps of daily tropospheric $\mathrm{NO}_{2}$ VCD averaged from September 2009 to March 2012. Overall, the spatial distribution and magnitude of tropospheric $\mathrm{NO}_{2}$ observed by SCIAMACHY are well reproduced by the model. This indicates that emission patterns and $\mathrm{NO}_{x}$ photochemistry are reasonably well represented by the model. However, the model underestimates tropospheric $\mathrm{NO}_{2} \mathrm{VCDs}$ over industrial areas in Europe, East China, Russia and Southeast Africa compared to satellite data. This could imply that anthropogenic emissions from RETRO-REAS are too low in these regions, or that the lifetime in the model

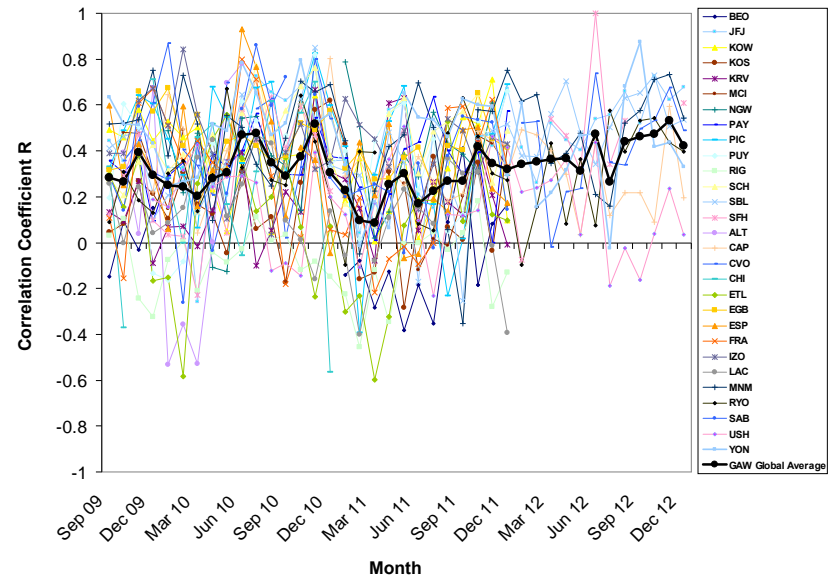

Figure 12. Correlation coefficient $(R)$, derived from the evaluation of the MACC_osuite with GAW CO surface observations over the period September 2009 to December 2012 (black line: global average of 29 GAW stations. Multi-coloured lines: individual station results; see legend to the right).

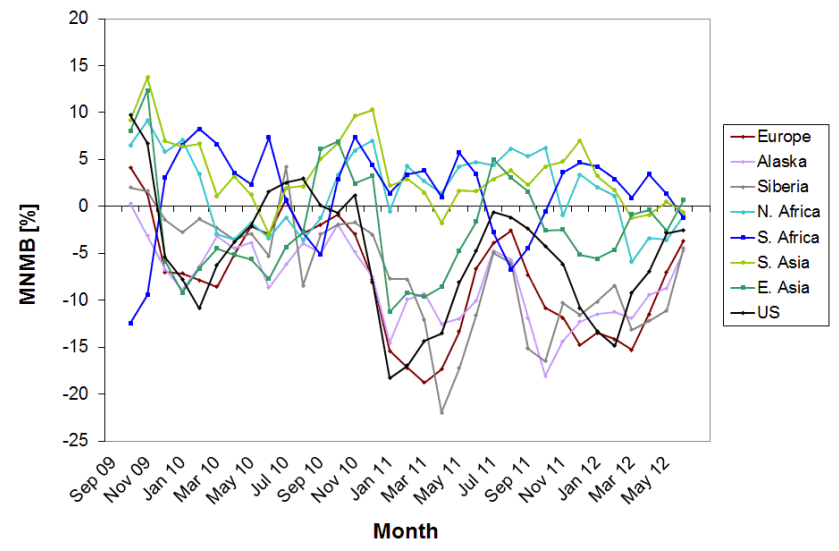

Figure 13. Monthly average of modified normalised mean biases (MNMBs in \%) derived from the comparison of the MACC_osuite with MOPITT CO total columns for eight different regions during the period September 2009 to June 2012 (see legend on the right).

is too short. The model simulates larger $\mathrm{NO}_{2} \mathrm{VCD}$ maxima over central Africa, which mainly originate from wild fires. It remains unclear if GFEDv2/GFAS fire emissions are too high here or if $\mathrm{NO}_{2}$ fire plumes closer to the ground cannot be seen by SCIAMACHY due to light scattering by biomass burning aerosols (Leitão et al., 2010). In the Northern Hemisphere, background values of $\mathrm{NO}_{2} \mathrm{VCD}$ over the ocean are lower in the simulations than in the satellite data. The same is true for the South Atlantic Ocean to the west of Africa (see Fig. 15). This might suggest a model underestimation of $\mathrm{NO}_{2}$ export from continental sources towards the ocean or too rapid conversion of $\mathrm{NO}_{2}$ into its reservoirs. However, as the $\mathrm{NO}_{2}$ columns over the oceans are close to the uncertainties in the satellite data, care needs to be taken when interpreting these differences. 

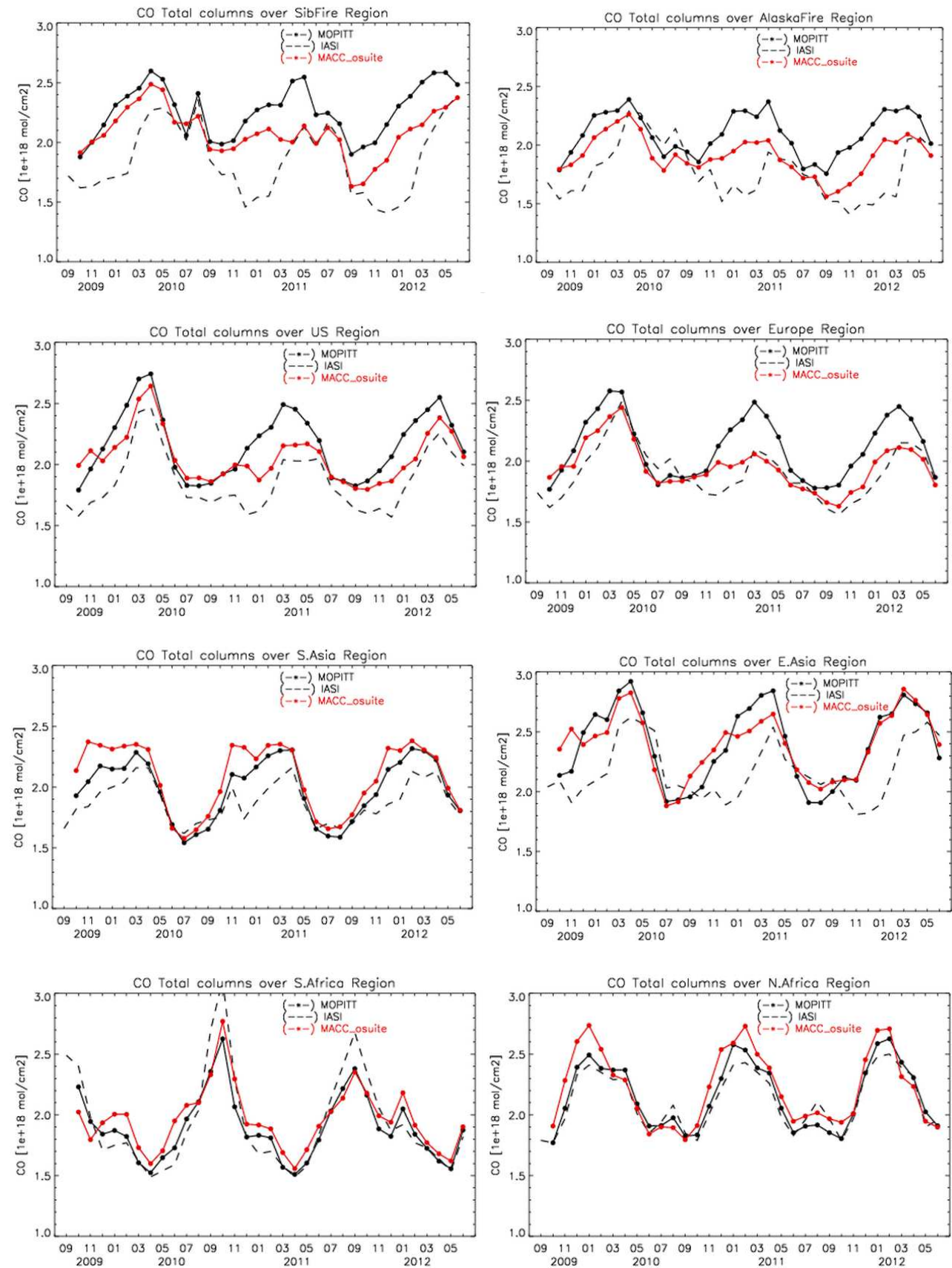

Figure 14. Time series plots of MOPITT CO total columns (black line) compared to IASI CO total columns (black dashed line) and the MACC_osuite CO total columns (red line) for eight different regions (defined in Fig. 1) during the period September 2009 to June 2012. Top: Siberia (left), Alaska (right), second row: United States (left), Europe (right), third row: South Asia (left), East Asia (right) bottom: southern Africa (left), North Africa (right).

Time series of daily tropospheric $\mathrm{NO}_{2} \mathrm{VCD}$ averaged over different regions and corresponding monthly means are presented in Figs. 16 and 17, respectively. Time series of the MNMB and RMSE are shown in Figs. 18 and 19, respectively. Table 7 summarises the statistical values derived over the whole time period. High anthropogenic emissions occur over the US, Europe, South Asia and East Asia compared to other regions on the globe (e.g. Richter et al., 2005). In principle, the MACC_osuite catches the pattern of satellite $\mathrm{NO}_{2}$ $\mathrm{VCD}$ over these regions. However, the model tends to underestimate $\mathrm{NO}_{2} \mathrm{VCDs}$ throughout the whole time period investigated here. The negative bias is most pronounced over East Asia with a modelled mean $\mathrm{NO}_{2}$ VCD for September 2009 to 

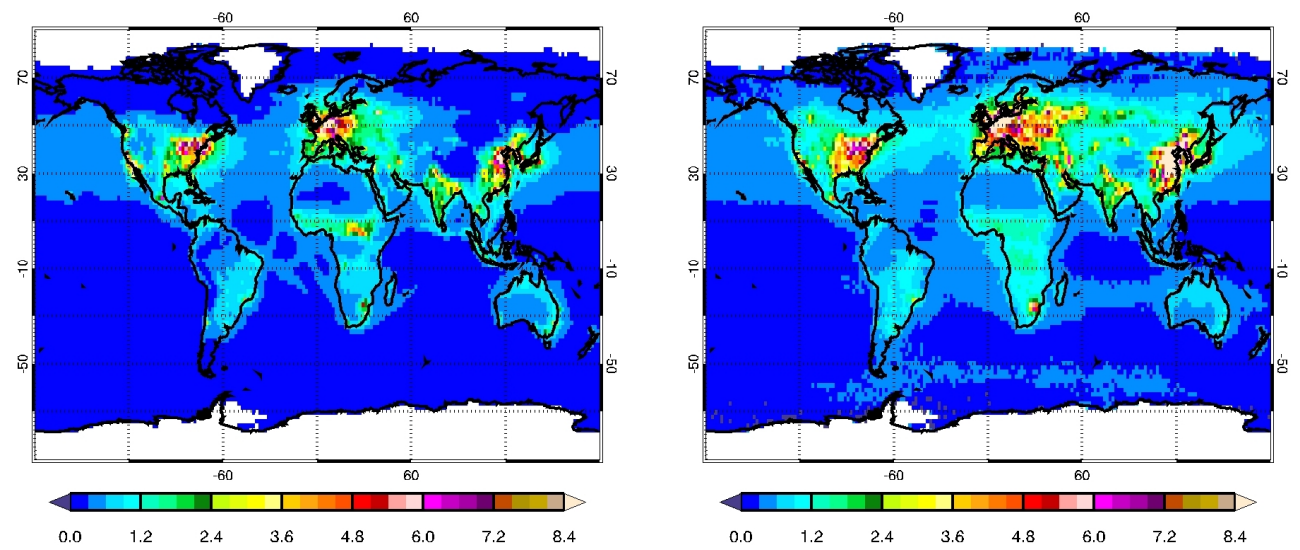

Figure 15. Long-term average of daily tropospheric $\mathrm{NO}_{2}$ VCD $\left[10^{15} \mathrm{molec} \mathrm{cm}^{-2}\right]$ from September 2009 to March 2012 for (left) MACC_osuite simulations and (right) SCIAMACHY satellite observations. Blue colours represent relatively low values; red/brown colours represent relatively high values.

Table 7. Statistics derived from satellite observations (SCIAMACHY from September 2009 until March 2012, GOME-2 from April 2012 to December 2012) and the MACC_osuite simulations of daily tropospheric $\mathrm{NO}_{2} \mathrm{VCD}\left[10^{15} \mathrm{molec}^{-2}\right]$ averaged over different regions for September 2009 to December 2012.

\begin{tabular}{lrrrrrr}
\hline Region & United States & Europe & South Asia & East Asia & Southern Africa & North Africa \\
\hline Model mean $\mathrm{NO}_{2} \mathrm{VCD}$ & 2.6 & 2.1 & 1.0 & 2.4 & 0.8 & 0.9 \\
{$\left[10^{15} \mathrm{molec}^{-2}\right.$ ] } & 3.1 & 3.6 & 1.2 & 6.2 & 1.1 & 0.9 \\
$\begin{array}{l}\text { Satellite mean } \mathrm{NO}_{2} \mathrm{VCD} \\
{\left[10^{15} \text { molec } \mathrm{cm}^{-2}\right]}\end{array}$ & -17.3 & -49.0 & -13.4 & -70.7 & -36.8 & -0.4 \\
$\begin{array}{l}\text { Modified normalised mean } \\
\text { bias (MNMB) [\%] }\end{array}$ & 1.2 & 2.0 & 0.3 & 6.0 & 0.5 & 0.3 \\
$\begin{array}{l}\text { Root mean square error } \\
\text { (RMSE) }\left[10^{15} \text { molec cm }{ }^{2}\right]\end{array}$ & 0.6 & 0.8 & 0.8 & 0.8 & 0.6 & 0.5 \\
$\begin{array}{l}\text { Correlation coefficient }(R) \\
\text { [dimensionless] }\end{array}$ & & & & & & \\
\hline
\end{tabular}

December 2012 of about $3.8 \times 10^{15}$ molec $\mathrm{cm}^{-2}$ lower than that derived from satellite measurements (see Table 7).

Considering monthly values, the MACC_osuite strongly underestimates magnitude and seasonal variation of satellite $\mathrm{NO}_{2} \mathrm{VCD}$ over East Asia (MNMBs between about -40 and $-110 \%$ and RMSE between $1 \times 10^{15}$ and $14 \times$ $10^{15}$ molec $\mathrm{cm}^{-2}$ throughout the whole time period). A change in the modelled $\mathrm{NO}_{2}$ values is apparent in July 2012 when the emission inventories changed and the agreement with the satellite data improved for South and East Asia but deteriorated for the US and Europe. This results in a drop of MNMBs (Fig. 18) for Europe and the US with values approaching around $-70 \%$ by the end of 2012 . Nevertheless, correlations between daily satellite and model data derived for the whole time period (see Table 7) are high for East Asia (0.8), South Asia (0.8), Europe (0.8), and lower, but still rather high, for the US (0.6).

The North African and southern African regions are strongly affected by biomass burning (Schreier et al., 2014). Magnitude and seasonality of daily and monthly tropo- spheric $\mathrm{NO}_{2}$ VCDs (Figs. 16 and 17, respectively) are rather well represented by the model, apart from January to October 2011, due to difficulties in reading fire emissions for this time period (see Sect. "Emission inventories and assimilated data sets"). The latter results in large absolute values of the MNMB (Fig. 18) and large RMSEs (Fig. 19) between January and October 2011 compared to the rest of the time period. As for other regions investigated in this section, mean values of simulated daily tropospheric $\mathrm{NO}_{2} \mathrm{VCDs}$ over North Africa and southern Africa between September 2009 and December 2012 tend to be lower than the corresponding satellite mean values (see Table 7). The correlation between daily model and satellite data over the whole time period is about 0.6 for southern Africa and 0.5 for North Africa. Whether this difference in model performance for the African regions is due to meteorology, chemistry or emissions needs to be investigated, but this is outside the scope of this paper.

The evaluation of modelled $\mathrm{NO}_{2}$ with GAW surface data for six European stations accordingly shows that $\mathrm{NO}_{2}$ is gen- 

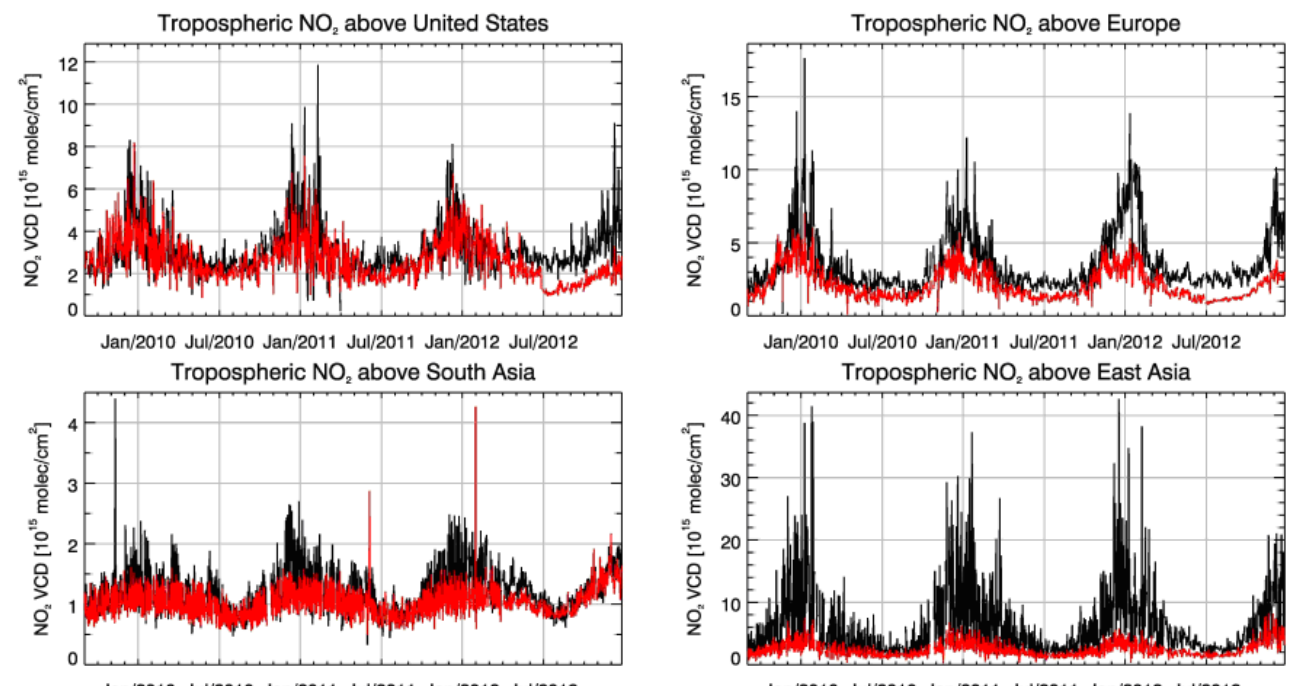

Jan/2010 Jul/2010 Jan/2011 Jul/2011 Jan/2012 Jul/2012 Tropospheric $\mathrm{NO}_{2}$ above southern Africa

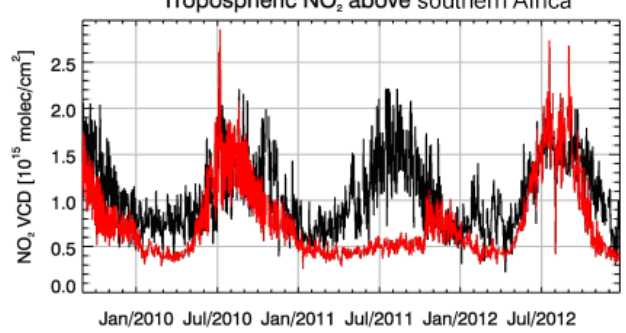
Tropospheric $\mathrm{NO}_{2}$ above North Africa

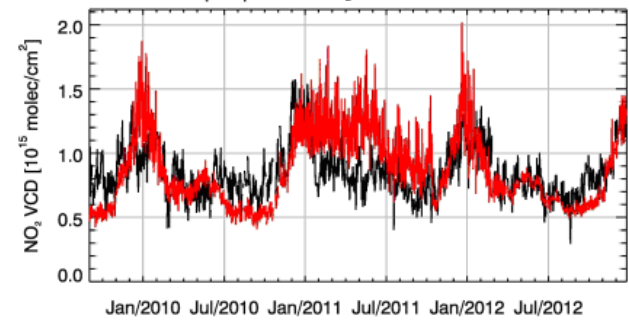

Figure 16. Time series of daily tropospheric $\mathrm{NO}_{2}$ VCD $\left[10^{15}\right.$ molec $\left.\mathrm{cm}^{-2}\right]$ averaged over different regions. Top: United States (left), Europe (right); second row: South Asia (left), East Asia (right); bottom: southern Africa (left), North Africa (right). Black lines show satellite observations (SCIAMACHY up to March 2012, GOME-2 from April 2012 to December 2012), red lines correspond to the MACC_osuite simulations.

Table 8. Modified normalised mean bias (MNMB) [\%], correlation coefficient $(R)$, and root mean square error (RMSE) $[\mathrm{ppb}]$ derived from the evaluation of the MACC_osuite with Global Atmospheric Watch (GAW) $\mathrm{NO}_{2}$ surface observations during the period September 2009 to December 2012. The conventional station names are listed in Table 3.

\begin{tabular}{lrrrrrr}
\hline Station & JFJ & KOW & KOS & RIG & SCH & SBL \\
\hline MNMB & -44.7 & -28.7 & -38.5 & 68.0 & -25.7 & -160.6 \\
$R$ & 0.2 & 0.6 & 0.4 & 0.2 & 0.4 & 0.1 \\
RMSE & 0.3 & 5.2 & 5.4 & 8.9 & 2.2 & 0.9 \\
\hline
\end{tabular}

erally underestimated at the surface. The MNMBs are typically in the range of -26 and $-45 \%$, larger MNMBs appear only for two stations in complex mountainous terrain (RIG $68 \%$ and SBL $-160 \%$ ). The RMSEs are between 0.3 and $9 \mathrm{ppb}$, and the correlation coefficients between 0.1 and 0.6 for the period between September 2009 and December 2012 (Table 8). The annual cycle of $\mathrm{NO}_{2}$ with maximum concentrations during the winter period is in principle captured by the model, shown in the time series plots in Fig. 20. As is observed for the satellite $\mathrm{VCDs}, \mathrm{NO}_{2}$ surface concentrations decrease in the model with the introduction of the updated model version and emission inventories. For stations located in complex terrain (e.g. Rigi, Fig. 20), results improve after the model update, likely also due to the higher model resolution. Monthly values of MNMB, $R$ and correlation coefficient are shown in Figs. 21 to 23.

\section{Discussion}

The validation of global $\mathrm{O}_{3}$ mixing ratios with GAW observations at the surface levels showed that the MACC_osuite could generally reproduce the observed annual cycle of ozone mixing ratios. Model validation with surface data shows global average monthly MNMBs between -30 and $30 \%$ (GAW) and for Europe between -50 and $60 \%$ (EMEP). For stations located in the northern mid-latitudes, the evaluation reveals a seasonally dependent bias, with an underestimation of the observed $\mathrm{O}_{3}$ mixing ratios by the MACC_osuite during the winter season and an overestimation during the summer months. The validation of daytime versus night-time concentrations for northern and central Europe shows larger negative MNMBs in the winter months during night-time than daytime (Fig. 8), so that the negative 

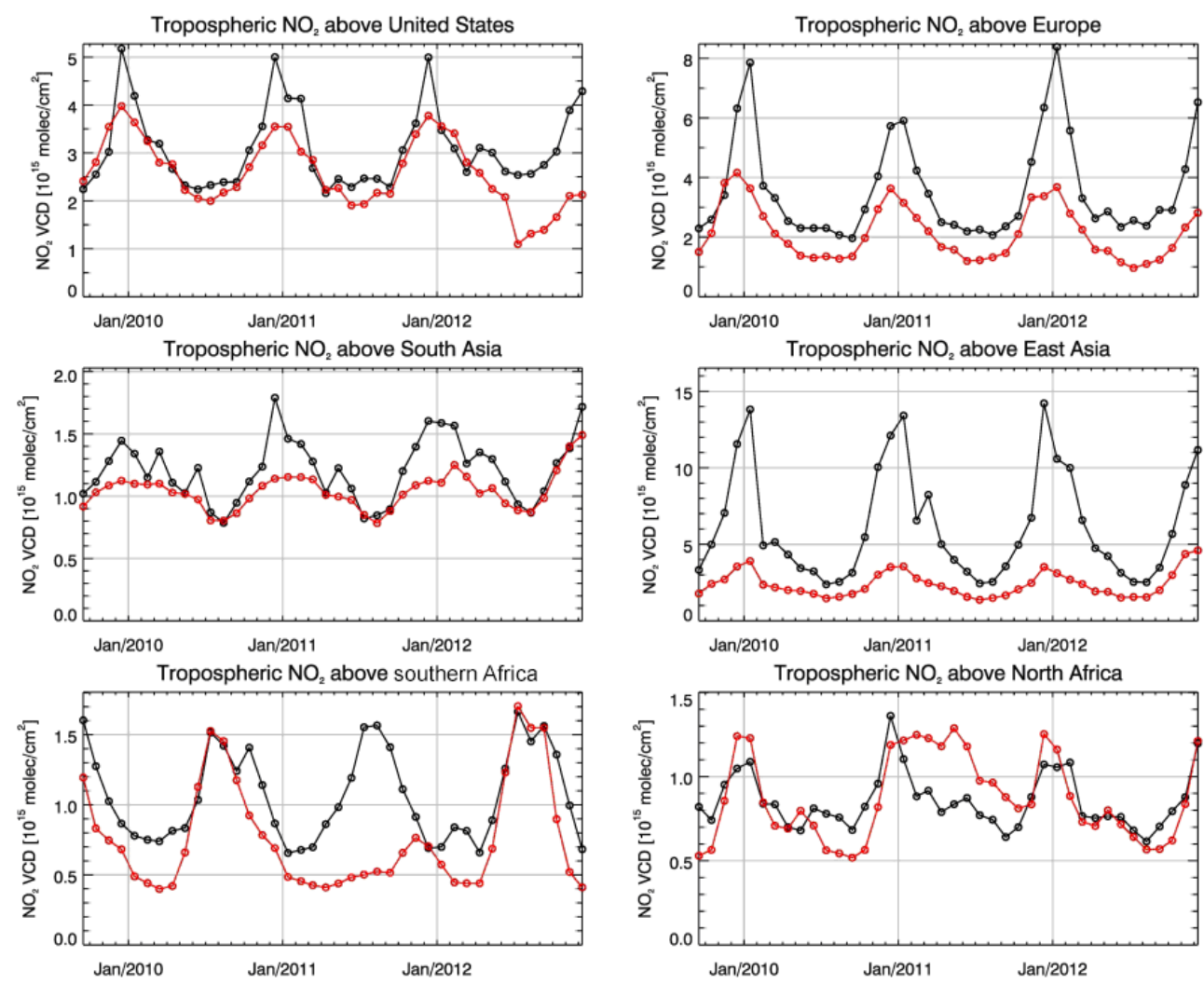

Figure 17. As in Fig. 16 but for monthly means of daily tropospheric $\mathrm{NO}_{2}$ VCD $\left[10^{15} \mathrm{molec}^{-2}\right]$ averaged over different regions. Top: United States (left), Europe (right); second row: South Asia (left), East Asia (right); bottom: southern Africa (left), North Africa (right).

bias in winter could be attributed to the simulation of vertical mixing at night, also described by Ordoñez et al. (2010) and Schaap et al. (2008), which remains a challenge for the model. The systematic underestimation of $\mathrm{O}_{3}$ mixing ratios throughout the year for high latitude northern regions and Antarctica has its origin in an overestimation of the $\mathrm{O}_{3}$ dry deposition velocities over ice. With the implementation of the new model cycle and the updated MOZART model version, which includes updated velocity fields for the dry deposition of $\mathrm{O}_{3}$, as described in Stein et al. (2013), the negative offset in the MACC_osuite model has been remedied for high latitude regions from July 2012 onwards (see the time series plots for the SPO and NEU in Fig. 3). The overestimation of $\mathrm{O}_{3}$ mixing ratios during the summer months is a wellknown issue and has been described by various model validation studies (e.g. Brunner et al., 2003; Schaap et al., 2008; Ordoñez et al., 2010; Val Martin et al., 2014). Inadequate ozone precursor concentrations and aerosol induced radiative effects (photolysis) have been frequently identified as being the main factors. The time series plots in Fig. 3, however, demonstrate that the minimum concentrations in particular are not captured by the model during summer. Possible explanations include a general underestimation of NO titration, which especially applies to stations with urban surroundings and strong sub-grid-scale emissions (e.g. TSU Fig. 3), including difficulties by the global model to resolve NO titration in urban plumes. It also seems likely that dry deposition at wet surfaces in combination with the large surface sink gradient due to nocturnal stability cannot be resolved with the model's relatively coarse vertical resolution. In regions such as central and southern Europe (Fig. 8) where daytime biases exceed night-time biases, the overestimation of $\mathrm{O}_{3}$ might be related to an underestimation of daytime dry deposition velocities. Val Martin et al. (2014) described a reduction of the summertime $\mathrm{O}_{3}$ model bias for surface ozone after the implementation of adjustments in stomatal resistances in the MOZART model's dry deposition parameterisation.

The MACC_osuite model realistically reproduces CO total columns over most of the evaluated regions with monthly MNMBs falling between 10 and $-20 \%$ (Table 6). There is close agreement of modelled CO total columns and satellite observations for Africa and South Asia throughout the evaluation period. However, there is a negative offset compared to the observational CO data over Europe and North America. The largest deviations occur during the winter season when the observed $\mathrm{CO}$ concentrations are at a highest level. The evaluation with GAW surface $\mathrm{CO}$ data accordingly shows a wintertime negative bias of up to $-35 \%$ in magni- 

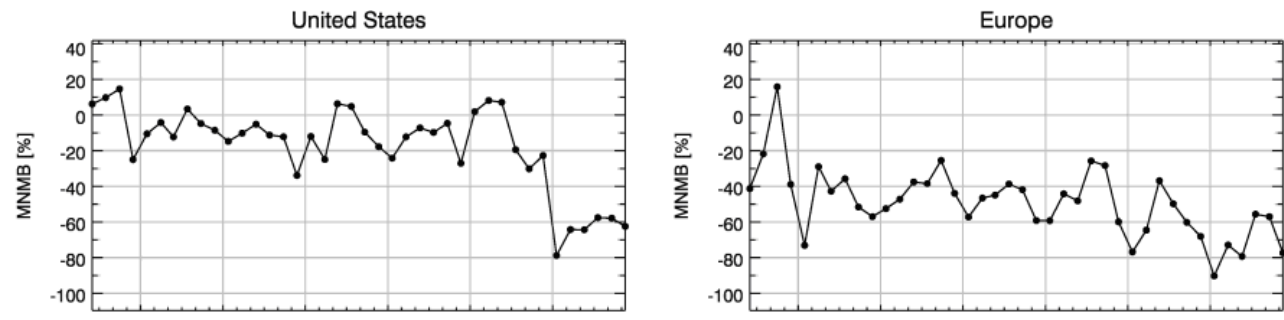

Jan/2010 Jul/2010 Jan/2011 Jul/2011 Jan/2012 Jul/2012 South Asia
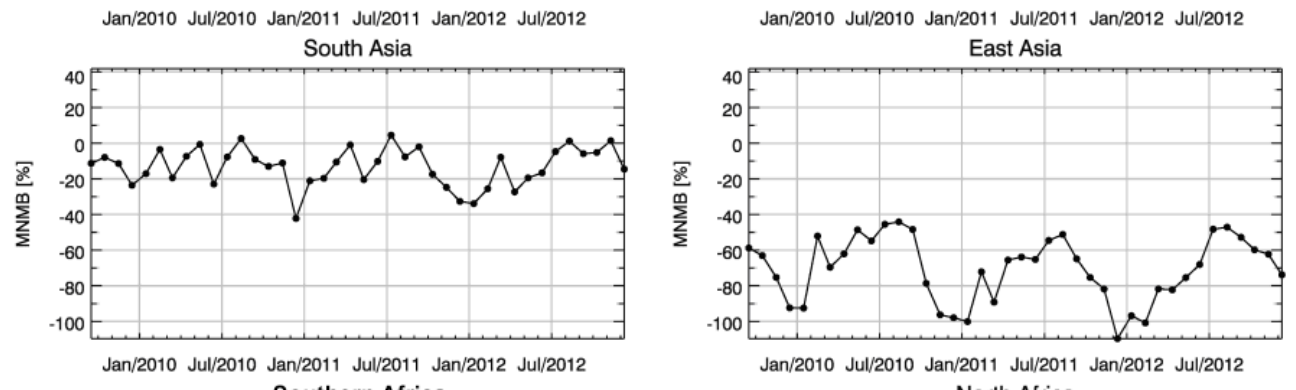
Southern Africa
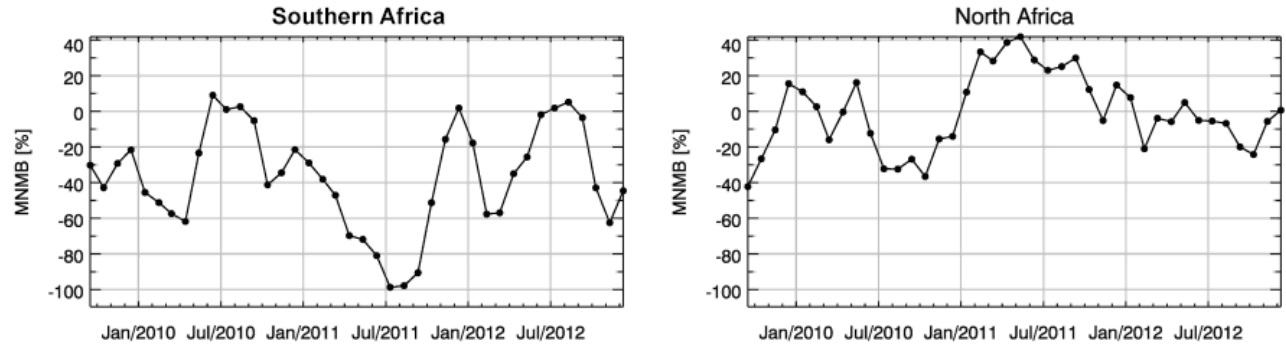

Figure 18. Modified normalised mean bias [\%] for monthly means of daily tropospheric $\mathrm{NO}_{2} \mathrm{VCD}$ averaged over different regions (see Fig. 1 for latitudinal and longitudinal boundaries) derived from the MACC_osuite simulations and satellite observations (SCIAMACHY up to March 2012, GOME-2 from April 2012 to December 2012). Top: United States (left), Europe (right), second row: South Asia (left), East Asia (right); bottom: southern Africa (left), North Africa (right). Values have been calculated separately for each month.

tude at the surface for stations in Europe and the US. A general underestimation of $\mathrm{CO}$ from global models in the Northern Hemisphere has been described by various authors (e.g. Shindell et al., 2006; Naik et al., 2013). According to Stein et al. (2014) this underestimation likely results from a combination of errors in the dry deposition parameterisation and certain limitations in the current emission inventories. The latter include too low anthropogenic $\mathrm{CO}$ emissions from traffic or other combustion processes and missing anthropogenic VOCs (Volatile Organic Compounds) emissions in the inventories together with an insufficiently established seasonality in the emissions. An additional reason for the apparent underestimation of emissions in MACCity may be an exaggerated downward trend in the RCP8.5 (Representative Concentration Pathways) scenario in North America and Europe between 2000 and 2010, as this scenario was used to extrapolate the MACCity emissions from their bench mark year, i.e. 2000. For CO, uncertainties in the evaluation also include the retrieved amount of $\mathrm{CO}$ total columns between IASI and MOPITT. These vary with region, with IASI showing lower $\mathrm{CO}$ concentrations in several regions (Alaska, Siberia, Europe and the US) during the northern winter months, which possibly contribute to the deviations observed between the modelled data and MOPITT satellite data, as only IASI data have been assimilated in the model. The differences can primarily be explained by the use of different a priori assumptions in the IASI and MOPITT retrieval algorithms (George et al., 2015). On a global scale, however, the average difference between the IASI and MOPITT total columns is less than $10 \%$ (George et al., 2009).

Modelled $\mathrm{NO}_{2}$ tropospheric columns agree well with satellite observations over the US, South Asia and North Africa. However, there is also a negative offset for $\mathrm{NO}_{2}$ over East Asia and Europe. For the latter, these findings are supported by the evaluation with GAW surface data. Again, the largest deviations occur during the winter season. The quality of the emission inventory is even more crucial for short-lived reactive species such as $\mathrm{NO}_{2}$, where model results depend to a large extent on emission inventories incorporated in the simulations. This is highlighted by the deterioration of agreement between model results and satellite data for the US in July 2012 when anthropogenic emissions were changed from RETRO-REAS to MACCity. This change led to an increasing negative bias in $\mathrm{NO}_{2}$ over Europe and North America and to an improvement for South and East Asia (see Fig. 18). A deterioration in MNMBs associated with the fire emissions is 


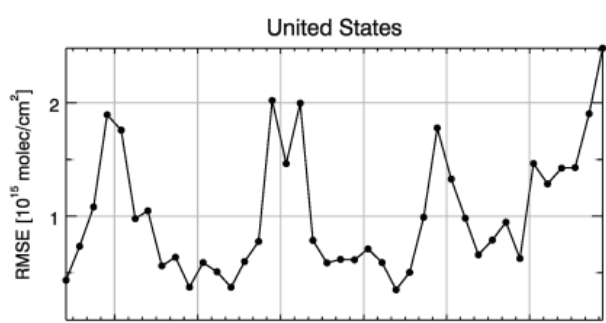

Jan/2010 Jul/2010 Jan/2011 Jul/2011 Jan/2012 Jul/2012 South Asia

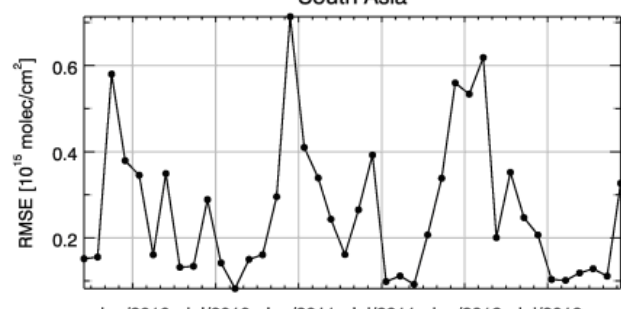

Jan/2010 Jul/2010 Jan/2011 Jul/2011 Jan/2012 Jul/2012 Southern Africa

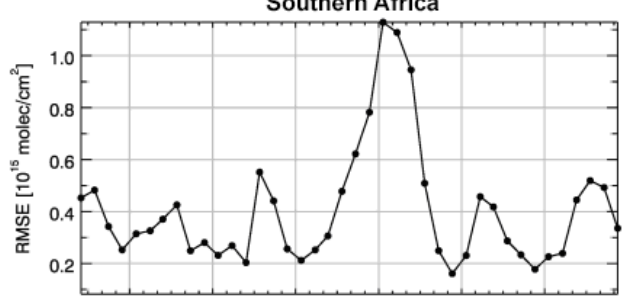

Jan/2010 Jul/2010 Jan/2011 Jul/2011 Jan/2012 Jul/2012

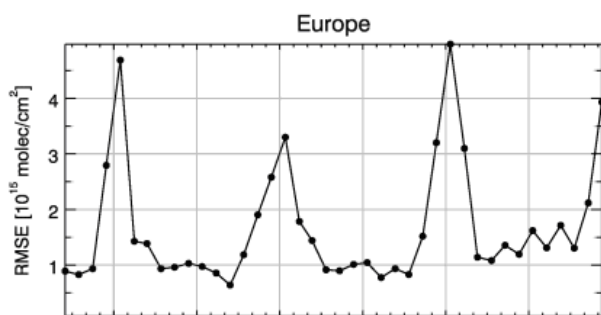

Jan/2010 Jul/2010 Jan/2011 Jul/2011 Jan/2012 Jul/2012

East Asia

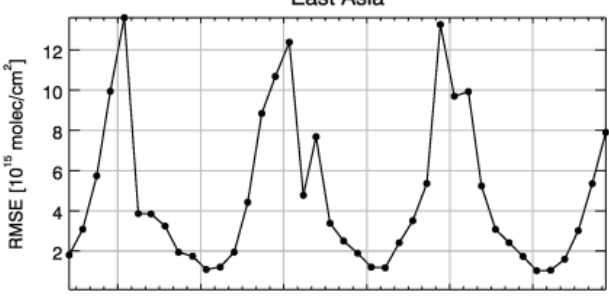

Jan/2010 Jul/2010 Jan/2011 Jul/2011 Jan/2012 Jul/2012 North Africa

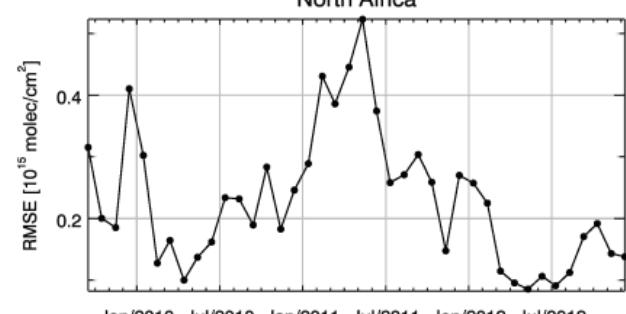

Jan/2010 Jul/2010 Jan/2011 Jul/2011 Jan/2012 Jul/2012

Figure 19. As in Fig. 18 but for the root mean square error $\left[10^{15}\right.$ molec $\left.\mathrm{cm}^{-2}\right]$.
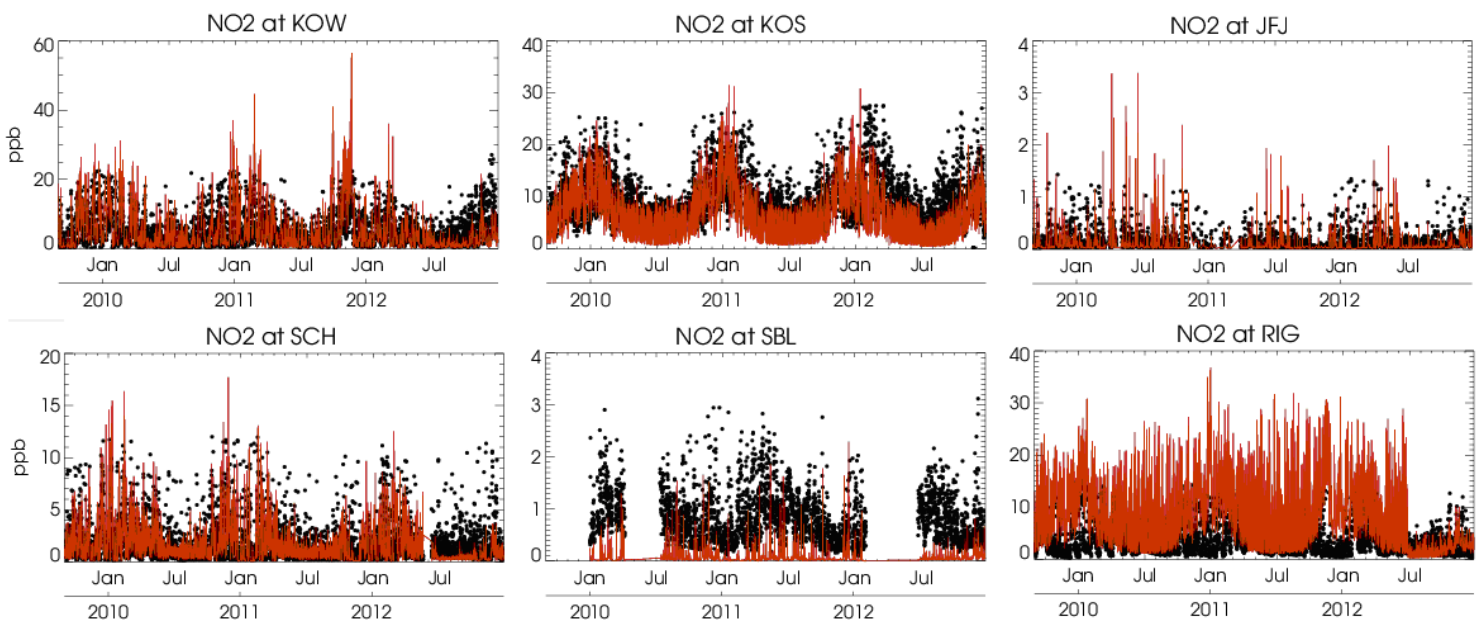

Figure 20. Time series plots of the MACC_osuite 6-hourly $\mathrm{NO}_{2}$ mixing ratios (red) and GAW surface observations (black) for Kollumerwaard, KOW (Netherlands); Kosetice, KOS (Czech Republic); Jungfraujoch, JFJ (Switzerland); Schauinsland, SCH (Germany); Sonnblick, SBL (Austria) and Rigi, RIG (Switzerland) during the period September 2009 to December 2012. Unit: ppb.

visible between January and October 2011 over regions with heavy fire activity (Africa and East Asia), and goes back to a temporary error in the model regarding the reading of fire emissions (see Figs. 16 to 18). Particular challenges for an operational forecast system are regions with rapid changes in emissions such as China, where emission inventories need to be extrapolated to analysis times of the MACC_osuite to obtain reasonable trends. The latter is done as emission inventories usually refer to times prior to MACC_osuite analysis times. A large underestimation of $\mathrm{NO}_{2}$ in China, especially in winter, has been reported for other CTMs in previous publications (He et al., 2007; Itahashi et al., 2014). The latter has 


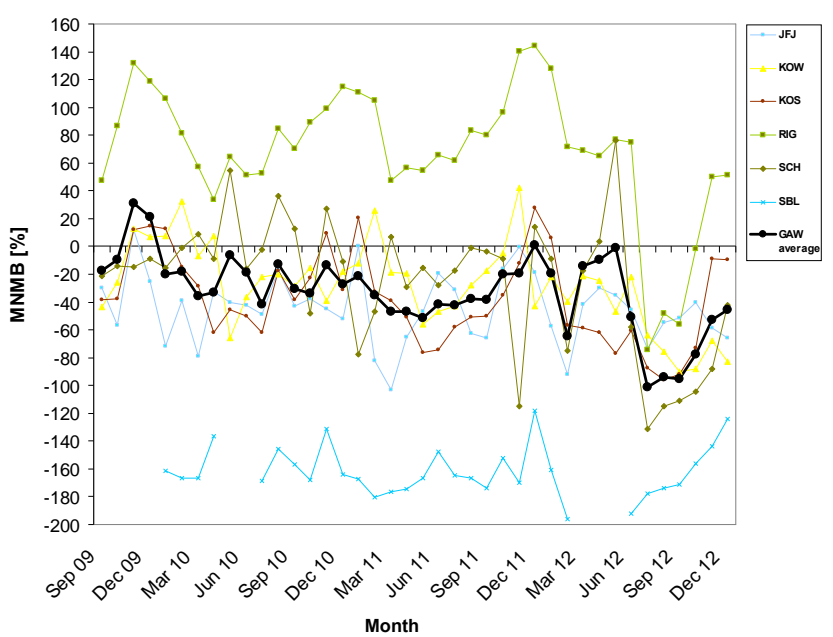

Figure 21. Modified normalised mean bias (MNMB) in \% derived from the evaluation of the MACC_osuite with GAW $\mathrm{NO}_{2}$ surface observations over the period September 2009 to December 2012 (black line: global average of six GAW stations, multi-coloured lines: individual station results; see legend to the right).

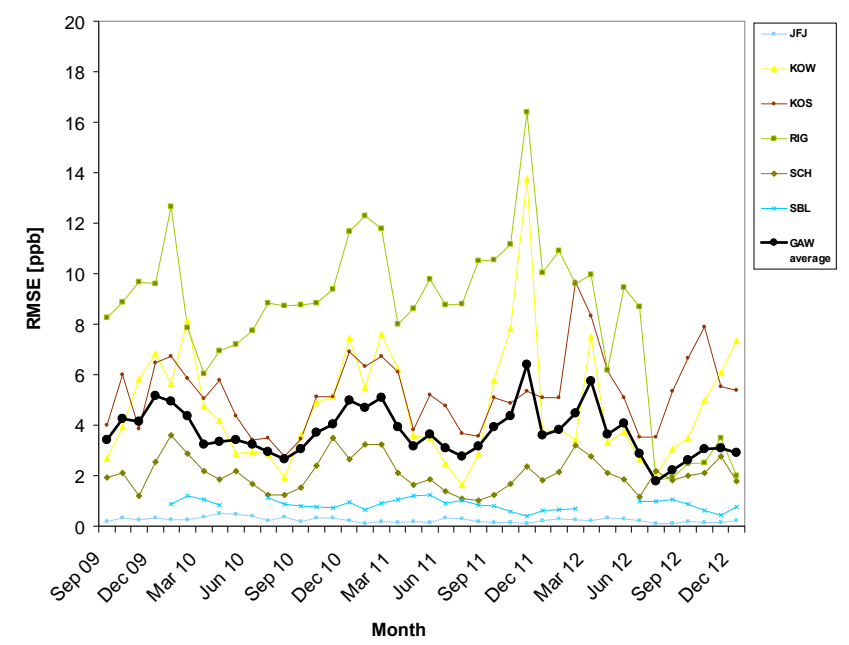

Figure 22. Root mean square error (RMSE) in ppb derived from the evaluation of the MACC_osuite with GAW NO 2 surface observations over the period September 2009 to December 2012 (black line: global average of six GAW stations, multi-coloured lines: individual station results; see legend to the right).

been linked to an underestimation of $\mathrm{NO}_{x}$ and VOC emissions, unresolved seasonality in the emissions and expected non-linearity of $\mathrm{NO}_{x}$ chemistry. The change in validation data sets from SCIAMACHY to GOME-2 has been shown to have negligible impact on the validation results and conclusions.

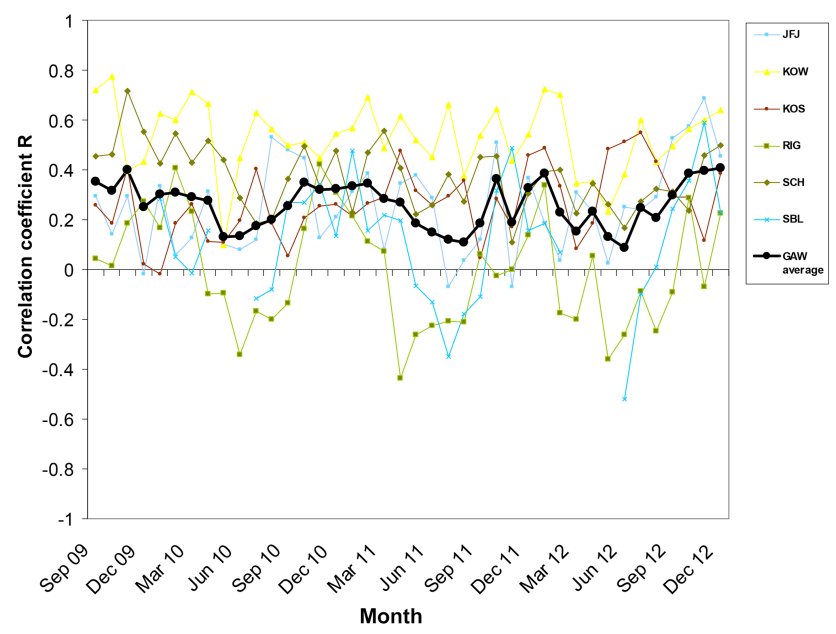

Figure 23. Correlation coefficient $(R)$, derived from the evaluation of the MACC_osuite with GAW NO 2 surface observations over the period September 2009 to December 2012 (black line: global average of 6 GAW stations, multi-coloured lines: individual station results; see legend to the right).

\section{Conclusion}

The MACC_osuite is the global near-real-time MACC model analysis run for aerosol and reactive gases. The model has been evaluated with surface observations and satellite data concerning its ability to simulate reactive gases in the troposphere. Results showed that the model proved capable of a realistic reproduction of the observed annual cycle for $\mathrm{CO}$, $\mathrm{NO}_{2}$ and $\mathrm{O}_{3}$ mixing ratios at the surface, however, with seasonally dependent biases. For ozone, these seasonal biases likely result from difficulties in the simulation of vertical mixing at night and deficiencies in the model's dry deposition parameterisation. For $\mathrm{CO}$, a negative offset in the model during the winter season is attributed to limitations in the emission inventories together with an insufficiently established seasonality in the emissions.

The $\mathrm{NO}_{2}$ total columns derived from satellite sensors and surface $\mathrm{NO}_{2}$ observed by European GAW stations could be reproduced reasonably well over most of the evaluated regions, but showed a negative offset compared to the observational data, especially over Europe and East Asia. It has become clear, that the emission inventories play a crucial role in the quality of model results and remain a challenge for near-real-time modelling, especially over regions with rapid changes in emissions. Inconsistencies in the assimilated satellite data and fire emissions showed only a temporary impact on the quality of model results. The implementation of a model update improved the results especially at high latitudes (surface ozone) and over South and East Asia.

The MACC NRT forecast system is constantly evolving. A promising step in model development is the online integration of modules for atmospheric chemistry in 
the IFS, currently being tested for implementation in the MACC_osuite (Flemming et al., 2015). In contrast to the coupled model configuration as used in this paper, the online integration in the Composition IFS (C-IFS) provides major advantages; apart from an enhanced computational efficiency, C-IFS promises an optimisation of the implementation of feedback processes between gas-phase/aerosol chemical processes and atmospheric composition and meteorology, which is expected to improve the modelling results for reactive gases. Additionally, C-IFS will be available in combination with different CTMs (MOZART and TM5), which will help to explain whether deviations between model and observations go back to deficiencies in the chemistry scheme of a model.

Acknowledgements. This work has been carried out in the framework of the MACC projects, funded under the EU Seventh Research Framework Programme for research and technological development. The authors thank the MACC validation and reactive gas subproject teams for fruitful discussions. Model simulations were carried out using the ECMWF supercomputer. We wish to acknowledge the provision of GAW hourly station data from the World Data Centre of Greenhouse Gases (WDCGG) and hourly EMEP station data from the Norwegian Institute for Air Research (NILU) database. Specifically, we like to thank the Commonwealth Scientific and Industrial Research Organisation (CSIRO) Oceans and Atmosphere Flagship for making the data freely available and the Australian Bureau of Meteorology for continued operation and support of the Cape Grim station. We also like to thank Izaña Atmospheric Research Center (AEMET) for providing $\mathrm{CO}$ and $\mathrm{O}_{3}$ data. Special thanks to the providers of NRT data to the MACC project, namely Institute of Atmospheric Sciences and Climate (ISAC) of the Italian National Research Council (CNR), South African Weather Service, The University of York and National Centre for Atmospheric Science (NCAS (AMF)) (UK), and the Instituto Nacional de Meteorologia e Geofisica (INMG) (Cape Verde), National Air Pollution Monitoring Network (NABEL) (Federal Office for the Environment FOEN and Swiss Federal Laboratories for Materials Testing and Research EMPA), Japan Meteorological Agency (JMA), Alfred Wegener Institute, Umweltbundesamt (Austria), National Meteorological Service (Argentina), Umweltbundesamt (UBA, Germany). We thank the National Center for Atmospheric Research (NCAR) MOPITT science team and the NASA Langley Research Center, Atmospheric Science Data Center (ASDC), for producing and archiving the MOPITT CO product. IASI has been developed and built under the responsibility of the Centre National D'Etudes Spatiales (CNES, France). We are grateful to Juliette Hadji-Lazaro and the ULB/LATMOS IASI team for establishing the IASI-MACC near-real-time processing chain. We wish to acknowledge that SCIAMACHY lv1 (level 1) radiances were provided to the Institute of Environmental Physics, University of Bremen by ESA through DLR/DFD.

Edited by: W. Lahoz

\section{References}

Aas, W., Hjellbrekke, A.-G., and Schaug, J.: Data quality 1998, quality assurance and field comparisons, Kjeller, Norwegian Institute for Air Research (EMEP/CCC-Report 6/2000), Oslo, Norway, 2000.

Ashmore, M. R.: Assessing the future global impacts of ozone on vegetation, Plant Cell Environ., 28, 949-964, 2005.

Ballabrera-Poy, J., Kalnay, E., and Yang, S.: Data assimilation in a system with two scales - combining two initialization techniques, Tellus, 61A, 539-549, doi:10.1111/j.16000870.2009.00400.x, 2009.

Bell, M. L., Peng, R. D., and Dominici, F.: The exposure-response curve for $\mathrm{O}_{3}$ and risk of mortality and the adequacy of current $\mathrm{O}_{3}$ regulations, Environ. Health Persp., 114, 532-536, 2006.

Benedetti, A., Morcrette, J.-J., Boucher, O., Dethof, A., Engelen, R. J., Fisher, M., Flentje, H., Huneeus, N., Jones, L., Kaiser, J. W., Kinne, S., Mangold, A., Razinger, M., Simmons, A. J., Suttie, M., and the GEMS-AER team: Aerosol analysis and forecast in the European Centre for Medium-Range Weather Forecasts Integrated Forecast System: Data Assimilation, J. Geophys. Res., 114, D13205, doi:10.1029/2008JD011115, 2008.

Benedetti, A., Kaiser, J. W., and Morcrette, J.-J.: Aerosols, B. Am. Meterol. Sci., 92, S65-S67, 2011.

Boersma, K. F., Eskes, H. J., and Brinksma, E. J.: Error analysis for tropospheric $\mathrm{NO}_{2}$ retrieval from space, J. Geophys. Res., 109, D04311, doi:10.1029/2003JD003962, 2004.

Bovensmann, H., Burrows, J. P., Buchwitz, M., Frerick, J., Noël, S., Rozanov, V. V., Chance, K. V., and Goede, A. P. H.: SCIAMACHY: Mission Objectives and Measurement Modes, J. Atmos. Sci., 56, 127-150, 1999.

Brunner, D., Staehelin, J., Rogers, H. L., Köhler, M. O., Pyle, J. A., Hauglustaine, D., Jourdain, L., Berntsen, T. K., Gauss, M., Isaksen, I. S. A., Meijer, E., van Velthoven, P., Pitari, G., Mancini, E., Grewe, G., and Sausen, R.: An evaluation of the performance of chemistry transport models by comparison with research aircraft observations. Part 1: Concepts and overall model performance, Atmos. Chem. Phys., 3, 1609-1631, doi:10.5194/acp-31609-2003, 2003.

Callies, J., Corpaccioli, E., Eisinger, M., Hahne, A., and Lefebvre, A.: GOME-2 Metop's Second-Generation Sensor for Operational Ozone Monitoring, ESA Bull., 102, 28-36, 2000.

Cape, J. N.: Surface ozone concentrations and ecosystem health: Past trends and a guide to future projections, Sci. Total Environ., 400, 257-269, doi:10.1016/j.scitotenv.2008.06.025, 2008.

Cuevas, E., Camino, C., Benedetti, A., Basart, S., Terradellas, E., Baldasano, J. M., Morcrette, J. J., Marticorena, B., Goloub, P., Mortier, A., Berjón, A., Hernández, Y., Gil-Ojeda, M., and Schulz, M.: The MACC-II 2007-2008 reanalysis: atmospheric dust evaluation and characterization over northern Africa and the Middle East, Atmos. Chem. Phys., 15, 3991-4024, doi:10.5194/acp-15-3991-2015, 2015.

Deeter, M. N., Emmons, L. K., Edwards, D. P., Gille, J. C., and Drummond, J. R.: Vertical resolution and information content of CO profiles retrieved by MOPITT, Geophys. Res. Lett., 31, L15112, doi:10.1029/2004GL020235, 2004.

Deeter, M. N., Edwards, D. P., Gille, J. C., Emmons, L. K., Francis, G., Ho, S.-P., Mao, D., Masters, D., Worden, H., Drummond, J. R., Novelli, P. C.: The MOPITT version 4 CO product: Algo- 
rithm enhancements, validation, and long-term stability, J. Geophys. Res., 115, D07306, doi:10.1029/2009JD013005, 2010.

Deeter, M. N., Martínez-Alonso, S., Edwards, D. P., Emmons, L. K., Gille, J. C., Worden, H. M., Pittman, J. V., Daube, B. C., and Wofsy, S. C.: Validation of MOPITT Version 5 thermalinfrared, near-infrared, and multispectral carbon monoxide profile retrievals for 2000-2011, J. Geophys. Res.-Atmos., 118, 6710-6725, doi:10.1002/jgrd.50272, 2013.

Elguindi, N., Clark, H., Ordóñez, C., Thouret, V., Flemming, J., Stein, O., Huijnen, V., Moinat, P., Inness, A., Peuch, V.-H., Stohl, A., Turquety, S., Athier, G., Cammas, J.-P., and Schultz, M.: Current status of the ability of the GEMS/MACC models to reproduce the tropospheric $\mathrm{CO}$ vertical distribution as measured by MOZAIC, Geosci. Model Dev., 3, 501-518, doi:10.5194/gmd-3501-2010, 2010.

Emmons, L. K., Edwards, D. P., Deeter, M. N., Gille, J. C., Campos, T., Nédélec, P., Novelli, P., and Sachse, G.: Measurements of Pollution In The Troposphere (MOPITT) validation through 2006, Atmos. Chem. Phys., 9, 1795-1803, doi:10.5194/acp-91795-2009, 2009.

Eskes, H., Huijnen, V., Arola, A., Benedictow, A., Blechschmidt, A.-M., Botek, E., Boucher, O., Bouarar, I., Chabrillat, S., Cuevas, E., Engelen, R., Flentje, H., Gaudel, A., Griesfeller, J., Jones, L., Kapsomenakis, J., Katragkou, E., Kinne, S., Langerock, B., Razinger, M., Richter, A., Schultz, M., Schulz, M., Sudarchikova, N., Thouret, V., Vrekoussis, M., Wagner, A., and Zerefos, C.: Validation of reactive gases and aerosols in the MACC global analysis and forecast system, Geosci. Model Dev., 8, 3523-3543, doi:10.5194/gmd-8-3523-2015, 2015.

Flemming, J. and Inness, A.: Volcanic sulfur dioxide plume forecasts based on UV satellite retrievals for the 2011 Grímsvötn and the 2010 Eyjafjallajökull eruption, J. Geophys. Res.-Atmos., 118, 10172-10189, doi:10.1002/jgrd.50753, 2013.

Flemming, J., Inness, A., Flentje, H., Huijnen, V., Moinat, P., Schultz, M. G., and Stein, O.: Coupling global chemistry transport models to ECMWF's integrated forecast system, Geosci. Model Dev., 2, 253-265, doi:10.5194/gmd-2-253-2009, 2009.

Flemming, J., Huijnen, V., Arteta, J., Bechtold, P., Beljaars, A., Blechschmidt, A.-M., Diamantakis, M., Engelen, R. J., Gaudel, A., Inness, A., Jones, L., Josse, B., Katragkou, E., Marecal, V., Peuch, V.-H., Richter, A., Schultz, M.-G., Stein, O., and Tsikerdekis, A.: Tropospheric chemistry in the Integrated Forecasting System of ECMWF, Geosci. Model Dev., 8, 975-1003, doi:10.5194/gmd-8-975-2015, 2015.

Forster, P., Ramaswamy, V., Artaxo, P., Berntsen, T., Betts, R., Fahey, D. W., Haywood, J., Lean, J., Lowe, D. C., Myhre, G., Nganga, J., Prinn, R., Raga, G., Schulz, M., and Van Dorland, R.: Changes in Atmospheric Constituents and in Radiative Forcing, in: Climate Change 2007: The Physical Science Basis. Contribution of Working Group I to the Fourth Assessment Report of the Intergovernmental Panel on Climate Change, edited by: Solomon, S., Qin, D., Manning, M., Chen, Z., Marquis, M., Averyt, K. B., Tignor, M., and Miller, H. L., USA, 2007.

George, M., Clerbaux, C., Hurtmans, D., Turquety, S., Coheur, P.F., Pommier, M., Hadji-Lazaro, J., Edwards, D. P., Worden, H., Luo, M., Rinsland, C., and McMillan, W.: Carbon monoxide distributions from the IASI/METOP mission: evaluation with other space-borne remote sensors, Atmos. Chem. Phys., 9, 8317-8330, doi:10.5194/acp-9-8317-2009, 2009.
George, M., Clerbaux, C., Bouarar, I., Coheur, P.-F., Deeter, M. N., Edwards, D. P., Francis, G., Gille, J. C., Hadji-Lazaro, J., Hurtmans, D., Inness, A., Mao, D., and Worden, H. M.: An examination of the long-term CO records from MOPITT and IASI: comparison of retrieval methodology, Atmos. Meas. Tech., 8, 43134328, doi:10.5194/amt-8-4313-2015, 2015.

Granier, C., Bessagnet, B., Bond, T., D’Angiola, A., van der Gon, H. D., Frost, G. J., Heil, A., Kaiser, J. W., Kinne, S., Klimont, Z., Kloster, S., Lamarque, J.-F., Liousse, C., Masui, T., Meleux, F., Mieville, A., Ohara, T., Raut, J. C., Riahi, K., Schultz, M. G., Smith, S. J., Thompson, A., van Aardenne, J., van der Werf, G. R., and van Vuuren, D. P.: Evolution of anthropogenic and biomass burning emissions of air pollutants at global and regional scales during the 1980-2010 period, Climatic Change, 109, 163-190, doi:10.1007/s10584-011-0154-1, 2011.

Guenther, A., Karl, T., Harley, P., Wiedinmyer, C., Palmer, P. I., and Geron, C.: Estimates of global terrestrial isoprene emissions using MEGAN (Model of Emissions of Gases and Aerosols from Nature), Atmos. Chem. Phys., 6, 3181-3210, doi:10.5194/acp-63181-2006, 2006.

He, Y., Uno, I., Wang, Z., Ohara, T., Sugimoto, N., Shimizu, A., Richter, A., and Burrows, J. P.: Variations of the increasing trend of tropospheric $\mathrm{NO}_{2}$ over central east China during the past decade, Atmos. Environ., 41, 4865-4876, 2007.

Hilboll, A., Richter, A., and Burrows, J. P.: Long-term changes of tropospheric $\mathrm{NO}_{2}$ over megacities derived from multiple satellite instruments, Atmos. Chem. Phys., 13, 4145-4169, doi:10.5194/acp-13-4145-2013, 2013a.

Hilboll, A., Richter, A., Rozanov, A., Hodnebrog, Ø., Heckel, A., Solberg, S., Stordal, F., and Burrows, J. P.: Improvements to the retrieval of tropospheric $\mathrm{NO}_{2}$ from satellite - stratospheric correction using SCIAMACHY limb/nadir matching and comparison to Oslo CTM2 simulations, Atmos. Meas. Tech., 6, 565-584, doi:10.5194/amt-6-565-2013, 2013b.

Hollingsworth, A., Engelen, R. J., Benedetti, A., Dethof, A., Flemming, J., Kaiser, J. W., and Simmons, A. J.: Toward a monitoring and forecasting system for atmospheric composition: The GEMS project, B. Am. Meteorol. Soc., 89, 1147-1164, doi:10.1175/2008BAMS2355.1, 2008.

Huijnen, V., Williams, J., van Weele, M., van Noije, T., Krol, M., Dentener, F., Segers, A., Houweling, S., Peters, W., de Laat, J., Boersma, F., Bergamaschi, P., van Velthoven, P., Le Sager, P., Eskes, H., Alkemade, F., Scheele, R., Nédélec, P., and Pätz, H.-W.: The global chemistry transport model TM5: description and evaluation of the tropospheric chemistry version 3.0, Geosci. Model Dev., 3, 445-473, doi:10.5194/gmd-3-445-2010, 2010.

Huijnen, V., Flemming, J., Kaiser, J. W., Inness, A., Leitão, J., Heil, A., Eskes, H. J., Schultz, M. G., Benedetti, A., Hadji-Lazaro, J., Dufour, G., and Eremenko, M.: Hindcast experiments of tropospheric composition during the summer 2010 fires over western Russia, Atmos. Chem. Phys., 12, 4341-4364, doi:10.5194/acp12-4341-2012, 2012.

Hurtmans, D., Coheur, P.-F., Wespes, C., Clarisse, L., Scharf, O., Clerbaux, C., Hadji-Lazaro, J., George, M., and Turquety, S.: FORLI radiative transfer and retrieval code for IASI, J Quant. Spectrosc. Ra., 113, 1391-1408, doi:10.1016/j.jqsrt.2012.02.036, 2012.

Inness, A., Flemming, J., Suttie, M., and Jones, L.: GEMS data assimilation system for chemically reactive gases. ECMWF RD 
Tech Memo 587, available at: http://www.ecmwf.int (last access: February 2015), 2009.

Inness, A., Baier, F., Benedetti, A., Bouarar, I., Chabrillat, S., Clark, H., Clerbaux, C., Coheur, P., Engelen, R. J., Errera, Q., Flemming, J., George, M., Granier, C., Hadji-Lazaro, J., Huijnen, V., Hurtmans, D., Jones, L., Kaiser, J. W., Kapsomenakis, J., Lefever, K., Leitão, J., Razinger, M., Richter, A., Schultz, M. G., Simmons, A. J., Suttie, M., Stein, O., Thépaut, J.-N., Thouret, V., Vrekoussis, M., Zerefos, C., and the MACC team: The MACC reanalysis: an $8 \mathrm{yr}$ data set of atmospheric composition, Atmos. Chem. Phys., 13, 4073-4109, doi:10.5194/acp-13-4073-2013, 2013.

Inness, A., Blechschmidt, A.-M., Bouarar, I., Chabrillat, S., Crepulja, M., Engelen, R. J., Eskes, H., Flemming, J., Gaudel, A., Hendrick, F., Huijnen, V., Jones, L., Kapsomenakis, J., Katragkou, E., Keppens, A., Langerock, B., de Mazière, M., Melas, D., Parrington, M., Peuch, V. H., Razinger, M., Richter, A., Schultz, M. G., Suttie, M., Thouret, V., Vrekoussis, M., Wagner, A., and Zerefos, C.: Data assimilation of satelliteretrieved ozone, carbon monoxide and nitrogen dioxide with ECMWF's Composition-IFS, Atmos. Chem. Phys., 15, 52755303, doi:10.5194/acp-15-5275-2015, 2015.

Itahashi, S., Uno, I., Irie, H., Kurokawa, J.-I., and Ohara, T.: Regional modeling of tropospheric $\mathrm{NO}_{2}$ vertical column density over East Asia during the period 2000-2010: comparison with multisatellite observations, Atmos. Chem. Phys., 14, 3623-3635, doi:10.5194/acp-14-3623-2014, 2014

Kaiser, J. W., Heil, A., Andreae, M. O., Benedetti, A., Chubarova, N., Jones, L., Morcrette, J.-J., Razinger, M., Schultz, M. G., Suttie, M., and van der Werf, G. R.: Biomass burning emissions estimated with a global fire assimilation system based on observed fire radiative power, Biogeosciences, 9, 527-554, doi:10.5194/bg-9-527-2012, 2012.

Kalnay, E.: Atmospheric Modeling, Data Assimilation and Predictability, Cambridge University Press, 2003.

Kalnay, E., Kanamitsu, M., Kistler, R., Collins, W., Deaven, D., Gandin, L., Iredell, M., Saha, S., White, G., Woollen, J., Zhu, Y., Chelliah, M., Ebisuzaki, W., Higgins, W., Janowiak, J., Mo, K. C., Ropelewski, C., Wang, J., Leetmaa, A., Reynolds, R., Jenne, R., and Joseph, D.: The NCEP/NCAR 40-Year Reanalysis Project, B. Am. Meteorol. Soc., 77, 437-471, doi:10.1175/15200477(1996)077<0437:TNYRP>2.0.CO;2, 1996.

Kampa, M. and Castanas, E.: Human health effects of air pollution, Environ. Pollut., 151, 362-367, 2008.

Kinnison, D. E., Brasseur, G. P., Walters, S., Gracia, R. R., Marsh, D. R., Sassi, F., Harvey, V. L., Randall, C. E., Emmons, L., Lamarque, J. F., Hess, P., Orlando, J. J., Tie, X. X., Randel, W., Pan, L. L., Gettelman, A., Granier, C., Diehl, T., Niemeier, U., and Simmons, A. J.: Sensitivity of chemical tracers to meteorological parameters in the MOZART-3 chemical transport model, J. Geophys. Res., 112, D20302, doi:10.1029/2006JD007879, 2007

Lefever, K., van der A, R., Baier, F., Christophe, Y., Errera, Q., Eskes, H., Flemming, J., Inness, A., Jones, L., Lambert, J.C., Langerock, B., Schultz, M. G., Stein, O., Wagner, A., and Chabrillat, S.: Copernicus stratospheric ozone service, 20092012: validation, system intercomparison and roles of input data sets, Atmos. Chem. Phys., 15, 2269-2293, doi:10.5194/acp-152269-2015, 2015.
Leitão, J., Richter, A., Vrekoussis, M., Kokhanovsky, A., Zhang, Q. J., Beekmann, M., and Burrows, J. P.: On the improvement of $\mathrm{NO}_{2}$ satellite retrievals - aerosol impact on the airmass factors, Atmos. Meas. Tech., 3, 475-493, doi:10.5194/amt-3-475-2010, 2010.

Massart, S., Agusti-Panareda, A., Aben, I., Butz, A., Chevallier, F., Crevoisier, C., Engelen, R., Frankenberg, C., and Hasekamp, O.: Assimilation of atmospheric methane products into the MACC-II system: from SCIAMACHY to TANSO and IASI, Atmos. Chem. Phys., 14, 6139-6158, doi:10.5194/acp-14-6139-2014, 2014.

Mohnen, V. A., Goldstein, W., and Wang, W.-C.: Tropospheric Ozone and Climate Change, Air \& Waste, 43, 1332-1334, doi:10.1080/1073161X.1993.10467207, 1993.

Naik, V., Voulgarakis, A., Fiore, A. M., Horowitz, L. W., Lamarque, J.-F., Lin, M., Prather, M. J., Young, P. J., Bergmann, D., Cameron-Smith, P. J., Cionni, I., Collins, W. J., Dalsøren, S. B., Doherty, R., Eyring, V., Faluvegi, G., Folberth, G. A., Josse, B., Lee, Y. H., MacKenzie, I. A., Nagashima, T., van Noije, T. P. C., Plummer, D. A., Righi, M., Rumbold, S. T., Skeie, R., Shindell, D. T., Stevenson, D. S., Strode, S., Sudo, K., Szopa, S., and Zeng, G.: Preindustrial to present-day changes in tropospheric hydroxyl radical and methane lifetime from the Atmospheric Chemistry and Climate Model Intercomparison Project (ACCMIP), Atmos. Chem. Phys., 13, 5277-5298, doi:10.5194/acp-13-5277-2013, 2013.

Ordóñez, C., Elguindi, N., Stein, O., Huijnen, V., Flemming, J., Inness, A., Flentje, H., Katragkou, E., Moinat, P., Peuch, V.-H., Segers, A., Thouret, V., Athier, G., van Weele, M., Zerefos, C. S., Cammas, J.-P., and Schultz, M. G.: Global model simulations of air pollution during the 2003 European heat wave, Atmos. Chem. Phys., 10, 789-815, doi:10.5194/acp-10-789-2010, 2010.

Penkett, S., Gilge, S., Plass-Duelmer, C., and Galbally, I.: WMO/GAW Expert Workshop on Global Long-term Measurements of Nitrogen Oxides and Recommendations for GAW Nitrogen Oxides Network, WMO, Geneva, 2011.

Platt, U. and Stutz, J.: Differential Optical Absorption Spectroscopy, Physics of Earth and Space Environments, Berlin: Springer, available at: http://www.springerlink.com/content/ 978-3-540-21193-8 (last access: February 2015), 2008.

Richter, A. and Burrows, J. P.: Tropospheric $\mathrm{NO}_{2}$ from GOME Measurements, Adv. Space Res., 29, 1673-1683, doi:10.1016/S0273-1177(02)00100-X, 2002.

Richter, A., Burrows, J. P., Nüß, H., Granier, C., and Niemeier, U.: Increase in tropospheric nitrogen dioxide over China observed from space, Nature, 437-132, doi:10.1038/nature04092, 2005.

Richter, A., Begoin, M., Hilboll, A., and Burrows, J. P.: An improved $\mathrm{NO}_{2}$ retrieval for the GOME-2 satellite instrument, Atmos. Meas. Tech., 4, 1147-1159, doi:10.5194/amt-4-1147-2011, 2011.

Rodgers, C. D.: Inverse Methods for Atmospheric Sounding, Theory and Practice, World Scientific, Singapore, 2000.

Rozanov, A., Vladimir, V., Rozanov, M., Buchwitz, A., Kokhanovsky, A., and Burrows, J. P.: SCIATRAN 2.0 - A New Radiative Transfer Model for Geophysical Applications in the $175-2400 \mathrm{Nm}$ Spectral Region, Adv. Space Res., 36, 1015-1019, doi:10.1016/j.asr.2005.03.012, 2005.

Santer, B. D., Sausen, R., Wigley, T. M. L., Boyle, J. S., AchutaRao, K., Doutriaux, C., Hansen, J. E., Meehl, G. A., Roeckner, E., Ruedy, R., Schmidt, G., and Taylor, K. E.: Behavior of 
tropopause height and atmospheric temperature in models, reanalyses, and observations: Decadal changes, J. Geophys. Res., 108, 4002, doi:10.1029/2002JD002258, 2003.

Savage, N. H., Agnew, P., Davis, L. S., Ordóñez, C., Thorpe, R., Johnson, C. E., O'Connor, F. M., and Dalvi, M.: Air quality modelling using the Met Office Unified Model (AQUM OS24-26): model description and initial evaluation, Geosci. Model Dev., 6, 353-372, doi:10.5194/gmd-6-353-2013, 2013.

Schaap, M., Renske, M. A., Timmermans, M. R., Boersen, G. A. C., and Builtjes, P. J. H.: The LOTOS-EUROS model: description, validation and latest developments, Int. J. Environ. Pollut., 32, 270-290, 2008.

Schreier, S. F., Richter, A., Kaiser, J. W., and Burrows, J. P.: The empirical relationship between satellite-derived tropospheric $\mathrm{NO}_{2}$ and fire radiative power and possible implications for fire emission rates of $\mathrm{NO}_{x}$, Atmos. Chem. Phys., 14, 2447-2466, doi:10.5194/acp-14-2447-2014, 2014.

Schultz, M. G., Backman, L., Balkanski, Y., Bjoerndalsaeter, S., Brand, R., Burrows, J. P., Dalsoeren, S., de Vasconcelos, M., Grodtmann, B., Hauglustaine, D. A., Heil, A., Hoelzemann, J. J., Isaksen, I. S. A., Kaurola, J., Knorr, W., LadstaetterWeißenmayer, B., Mota, A., Oom, D., Pacyna, J., Panasiuk, D., Pereira, J. M. C., Pulles, T., Pyle, J., Rast, S., Richter, A., Savage, N., Schnadt, C., Schulz, M., Spessa, A., Staehelin, J., Sundet, J. K., Szopa, S., Thonicke, K., van het, Bolscher, M., van Noije, T., van Velthoven, P., Vik, A. F., and Wittrock, F.: REanalysis of the TROpospheric chemical composition over the past 40 years (RETRO) - A long-term global modeling study of tropospheric chemistry, Final Report Jülich/ Hamburg, Germany, published as report no. 48/2007 in the series, Reports on Earth System Science" of the Max Planck Institute for Meteorology, Hamburg, ISSN 1614-1199, 2007.

Seinfeld, J. H. and Pandis, S. N.: Atmospheric Chemistry and Physics: From Air Pollution to Climate Change, John Wiley, Hoboken, N. J., 2006.

Selin, N. E., Wu, S., Reilly, J. M., Paltsev, S., Prinn, R. G., and Webster, M. D.: Global health and economic impacts of future ozone pollution, Environ. Res. Lett., 4, 044014, doi:10.1088/17489326/4/4/044014, 2009.

Sheel, V., Sahu, L. K., Kajinu, M., Deushi, M., Stein, O., and Nedelec, P.: Seasonal and interannual variability of carbon monoxide based on MOZAIC observations, MACC reanalysis, and model simulations over an urban site in India, J. Geophys. Res., 119, 9123-9141, 2014.

Shindell, D. T., Faluvegi, G., Stevenson, D. S., Krol, M. C., Emmons, L. K., Lamarque, J.-F., Petron, G., Dentener, F. J., Ellingsen, K., Schultz, M. G., Wild, O., Amann, M., Atherton, C. S., Bergmann, D. J., Bey, I., Butler, T., Cofala, J., Collins, W. J., Derwent, R. G., Doherty, R. M., Drevet, J., Eskes, H. J., Fiore, A. M., Gauss, M., Hauglustaine, D. A., Horowitz, L. W., Isaksen, I. S. A., Lawrence, M. G., Montanaro, V., Müller, J.-F., Pitari, G., Prather, M. J., Pyle, J. A., Rast, S., Rodriguez, J. M., Sanderson, M. G., Savage, N. H., Strahan, S., E., Sudo, K., Szopa, S., Unger, N., van Noije, T. P. C., and Zeng, G.: Multimodel simulations of carbon monoxide: Comparison with observations and projected near-future changes, J. Geophys. Res., 111, D19306, doi:10.1029/2006JD007100, 2006.

Sinnhuber, B. M., Weber, M., Amankwah, A., and Burrows, J. P.: Total Ozone during the Unusual Antarctic Winter of 2002, Geo- phys. Res. Lett., 30, 1580-1584, doi:10.1029/2002GL016798, 2003.

Sinnhuber, M., Burrows, J. P., Chipperfield, M. P., Jackman, C. H., Kallenrode, M.-B., Künzi, K. F., and Quack, M.: A Model Study of the Impact of Magnetic Field Structure on Atmospheric Composition during Solar Proton Events, Geophys. Res. Lett., 30, 1818-1821, doi:10.1029/2003GL017265, 2003.

Sitch, S., Cox, P. M., Collins, W. J., Huntingford, C.: Indirect radiative forcing of climate change through ozone effects on the landcarbon sink, Nature, 448, 791-794, doi:10.1038/nature06059, 2007.

Stein, O., Schultz, M. G., Flemming, J., Inness, A., Kaiser, J., Jones, L., Benedetti, A., and Morcrette, J.-J.: MACC Global air quality services - Technical Documentation, MACC project deliverable D_G-RG_3.8, available at: www.gmes-atmosphere.eu/ documents/deliverables/g-rg/ (last access: February 2015), 2011.

Stein, O., Flemming, J., Inness, A., Kaiser, J. W., and Schultz, M. G.: Global reactive gases and reanalysis in the 5 MACC project, J. Integr. Environ. Sci., 9, 57-70, doi:10.1080/1943815X.2012.696545, 2012.

Stein, O., Huijnen, V., and Flemming, J.: Model description of the IFS-MOZART and IFS-TM5 coupled systems, MACC-II project deliverable D_55.4, available at: https://www.gmes-atmosphere. eu/documents/maccii/deliverables/grg/ (last access: February 2015), 2013.

Stein, O., Schultz, M. G., Bouarar, I., Clark, H., Huijnen, V., Gaudel, A., George, M., and Clerbaux, C.: On the wintertime low bias of Northern Hemisphere carbon monoxide found in global model simulations, Atmos. Chem. Phys., 14, 9295-9316, doi:10.5194/acp-14-9295-2014, 2014.

Tørseth, K., Aas, W., Breivik, K., Fjæraa, A. M., Fiebig, M., Hjellbrekke, A. G., Lund Myhre, C., Solberg, S., and Yttri, K. E.: Introduction to the European Monitoring and Evaluation Programme (EMEP) and observed atmospheric composition change during 1972-2009, Atmos. Chem. Phys., 12, 5447-5481, doi:10.5194/acp-12-5447-2012, 2012.

Valcke, S. and Redler, R.: OASIS4 User Guide (OASIS4_0_2). PRISM-Support Initiative, Technical Report No 4, available at: http://www.prism.enes.org/Publications/Reports/OASIS4_User_ Guide_T4.pdf (last access: February 2015), 2006.

Val Martin, M., Heald, C. L., and Arnold, S. R.: Coupling dry deposition to vegetation phenology in the Community Earth System Model: Implications for the simulation of surface $\mathrm{O}_{3}$, Geophys Res. Lett., 41, 2988-2996, doi:10.1002/2014GL059651, 2014.

van der Werf, G. R., Randerson, J. T., Giglio, L., Collatz, G. J., Kasibhatla, P. S., and Arellano Jr., A. F.: Interannual variability in global biomass burning emissions from 1997 to 2004, Atmos. Chem. Phys., 6, 3423-3441, doi:10.5194/acp-6-3423-2006, 2006.

Wang, P., Stammes, P., van der A, R., Pinardi, G., and van Roozendael, M.: FRESCO+: an improved $\mathrm{O}_{2}$ A-band cloud retrieval algorithm for tropospheric trace gas retrievals, Atmos. Chem. Phys., 8, 6565-6576, doi:10.5194/acp-8-6565-2008, 2008.

Winkler, H., Sinnhuber, M., Notholt, J., Kallenrode, M. B., Steinhilber, F., Vogt, J., Zieger, B., Glassmeier, K. H., and Stadelmann, A.: Modeling impacts of geomagnetic field variations on middle atmospheric ozone responses to solar proton events on long timescales, J. Geophys. Res., 113, D02302, doi:10.1029/2007JD008574, 2008. 
WMO: WMO Global Atmosphere Watch (GAW) Strategic Plan: 2008-2015, World Meteorological Organization, Geneva, Switzerland, 2007.

WMO: Guidelines for the Measurement of Atmospheric Carbon Monoxide, GAW Report No. 192, World Meteorological Organization, Geneva, Switzerland, 2010.

WMO: WMO/GAW Expert Workshop on Global Long-term Measurements of Nitrogen Oxides and Recommendations for GAW Nitrogen Oxides Network, GAW Report No. 195, World Meteorological Organization, Geneva, Switzerland, 2011.

WMO: 16th WMO/IAEA Meeting on Carbon Dioxide, Other greenhouse Gases and Related Measurement Techniques (GGMT-2011), Geneva, 2012.
WMO: Guidelines for the Continuous Measurements of Ozone in the Troposphere, GAW Report No. 209, World Meteorological Organization, Geneva, Switzerland, 2013.

Worden, H. M., Deeter, M. N., Edwards, D. P., Gille, J., Drummond, J., Emmons, L. K., Francis, G., and Martínez-Alonso, S.: 13 years of MOPITT operations: lessons from MOPITT retrieval algorithm development, Ann. Geophys., 56, doi:10.4401/ag-6330, 2014. 